\title{
Termolecular Ion-Molecule Reactions in Titan's Atmosphere. IV. A Search Made at Up to 1 Micron in Pure Hydrocarbons
}

\author{
Vincent G. Anicich \\ Jet Propulsion Laboratory, California Institute of Technology, Pasadena, California, USA
}

\author{
Paul Wilson and Murray J. McEwan \\ Department of Chemistry, University of Canterbury, Christchurch, New Zealand
}

\begin{abstract}
The results of a study of ion-molecule reactions occurring in pure methane, acetylene, ethylene, ethane, propyne, propene, propane, and diacetylene at pressures up to 40 microns of pressure are reported. A variety of experimental methods are used: The standard double resonance in an ICR, for determination of the precursor ions and the modulated double resonance ejection in an ICR, for the determination of the daughter ions. The FA-SIFT technique was used for validation and examination of termolecular reactions with rate coefficients that are less than $10^{-26} \mathrm{~cm}^{6} \mathrm{~s}^{-1}$. An extensive database of reaction kinetics already exists for many of these reactions. The main point of this study was the determination of the accuracy of this database and to search for any missing reactions and reaction channels that may have been omitted from earlier investigations. A specific objective of this work was to extend the study to the highest pressures possible to find out if there were any important termolecular reaction channels occurring. A new approach was used here. In the pure hydrocarbon gases the mass spectra were followed as a function of the pressure changes of the gas. An initial guess was first made using the current literature as a source of the reaction kinetics that were expected. A model of the ion abundances was produced from the solution of the partial differential equations in terms of reaction rate coefficients and initial abundances. The experimental data was fitted to the model for all of the pressures by a least squares minimization to the reaction rate coefficients and initial abundances. The reaction rate coefficients obtained from the model were then compared to the literature values. Several new channels and reactions were discovered when the modeled fits were compared to the actual data. This is all explained in the text and the implications of these results are discussed for the Titan atmosphere. (J Am Soc Mass Spectrom 2003, 14, 900-915) (c) 2003 American Society for Mass Spectrometry
\end{abstract}

$\mathrm{T}$ This is the fourth in a series of articles on the ion-molecule chemistry that is expected to occur in the atmosphere of Saturn's satellite Titan. The first three articles described the reactions of the principal ions with the principal neutrals [1], the structure of the association adducts of $\mathrm{HCNH}^{+}$with $\mathrm{C}_{2} \mathrm{H}_{2}$ and $\mathrm{C}_{2} \mathrm{H}_{4}$ [2], and the clustering of $\mathrm{HCNH}^{+}$with nitrogen [3]. In this present paper we relate experimental results on the ion-molecule reactions of the parent hydrocarbon ions and daughter ions with the hydrocarbons: methane, acetylene, ethane, propyne, propene, propane, and diacetylene. In this work we present several

Published online July 2, 2003

Address reprint requests to Dr. V. G. Anicich, Jet Propulsion Laboratory, California Institute of Technology, 4800 Oak Grove Drive, M/S 183-301,

Pasadena, CA 91109-8099, USA. E-mail: vincent.g.anicich@jpl.nasa.gov new channels of the known reactions that were not previously reported and in addition we observed several termolecular association reactions that have significant influence on the ion abundances. It was necessary to include these new reactions to describe the chemistry occurring in the ion cyclotron resonance (ICR) spectrometer at total pressures up to about 40 microns in the case of methane.

In previous studies the chemistry was examined under conditions in which the reactant ion was the predominate ion, if not the only ion. In many of the current studies, several ions were present. In these cases reaction rate coefficients were obtained through numerical modeling of the chemistry. The reaction rate coefficients and initial abundances were varied to fit the data. In the extrapolation of the laboratory data to the actual environment of Titan it is seen that many con- 
secutive reactions take place after the initial ionization of the nitrogen occurs [4]. As the size of the ions increase the question is raised as to which isomer or isomers are actually present. Since different isomers may often react with different rates, it is important to determine the chemistry of the actual isomer of interest. We have chosen to follow the ion reaction scheme from the initial parent ions. It is then expected that the isomers produced in our studies will be representative of the ions present in Titan's actual atmosphere. So, by studying the chemistry at pressures up to 1 micron and following several consecutive reactions, the results should be more representative of Titan chemistry than the lower-pressure individual ion studies. It will be seen that the product ions are not thermalized in the ICR. When these non-thermal ions undergo subsequent reactions, they exhibit reaction rate coefficients and branching ratios that are different from the thermalized ions. How this relates to Titan is not clear, since the majority of the hydrocarbon ions in the atmosphere are made through exothermic ion molecule reactions. Is there enough time between collisions in Titan's atmosphere for the ions to be thermalized? This depends on where in the atmosphere the ion exists and the amount of internal energy that it contains. It is expected that the product channels detected in the ICR will be similar to those that occur in Titan's atmosphere and that the reaction rate coefficient will be at least a lower limit in most cases. It will be seen in the next paper in this series that even in the SIFT experiment, the reaction rate coefficients of some exothermic product ions are less than their thermalized values.

We understand that Titan's atmosphere is not made up of pure hydrocarbons. It is by no means a simple problem to reproduce the conditions in Titan's atmosphere in the laboratory. We can only approach it. These pure systems examined here are not close approximations at all at first glance, but if they are taken as a first step they can be of value. Subsequent work is envisioned to approach the Titan atmosphere in steps. One of the next steps is to look at the reactions of the $\mathrm{N}^{+}$ and $\mathrm{N}_{2}^{+}$ions in detail up to high abundances of the pure gases methane, acetylene, and ethylene. Another step is to look at the cross reactions that are not seen in the pure systems. And a final step is to look at the reactions of the $\mathrm{N}^{+}$and $\mathrm{N}_{2}^{+}$ions in a mixture of methane, acetylene, and ethylene in proportions found in Titan's atmosphere. All of these later steps require that we have a good understanding of the reactions in these pure systems first. It will make the following steps easier.

Current modeling of Titan's atmosphere has shown that the ion chemistry can be important in determining the neutral abundances of some of the trace species [5]. The models of Titan's atmosphere show that up to the altitude where the electron density peaks, very complex chemical structures are being produced and the laboratory data do not extend to these species or pressures. The present study will help in removing this deficiency.

\section{Experimental}

In these studies, both ion cyclotron resonance (ICR) mass spectrometry and flowing afterglow-selected ion flow tube (FA-SIFT) techniques were used. All experiments were made at room temperature, about $295 \mathrm{~K}$.

The ICR was at the Jet Propulsion Laboratory and has been described before [6]. The details needed for this paper will be summarized below. The instrument used a twelve inch electromagnet, which was normally set at 1.5 tesla for these experiments. The ICR cell was used in the drift mode. The cell had two sections, a source section and a resonance section. Ions were produced in the source section by means of an electron beam. Electron energies were kept at less than one electron volt above the ionization potential required to produce the desired ion. The ions drifted from the source to the resonance sections using the Lorentz force. The Wronka bridge detector [7] was attached to the drift plates of the resonance section for the detection of the relative ion abundances. Gas pressures were measured using a Bayard-Alpert ionization gauge, which was calibrated against a 1 torr MKS Baratron capacitance manometer in the $10^{-5}$ torr pressure range. Above $1 \times$ $10^{-4}$ torr the MKS Baratron manometer was used directly to measure the pressure. The mass spectra were taken by scanning the cyclotron frequencies and using a Wronka bridge detector for the relative measurements of ion abundances. Phase sensitive detection was used to measure the signal from the bridge detector. Modulation of the ionizing electron beam was used for the mass spectra and the double resonance experiments [8]. A double resonance radio-frequency (rf) was used to search for precursor ions by observing individual ion peaks and radiating the double resonance rf in both the source and resonance regions of the drift cell. Double resonance coupling was identified when the product ion was lost by irradiation at the cyclotron frequency of the parent ion. Loss of the product ion signal was noted using the Wronka bridge detector, which was set at the product ion cyclotron frequencies. A modulated ejection at the double resonance frequency of selected parent ions along with frequency scans of the Wronka bridge detector was used to identify the product ions formed from the selected parent ions. Between the direct double resonance ejection experiments and the modulated ejection double resonance experiments, all significant reaction links between ions were determined.

The tandem FA-SIFT experiment was at the University of Canterbury and has also been described previously [9]. A summary follows for the understanding of this paper. The ions are formed in a flowing afterglow tube and mass selectively injected into the SIFT section through a Venturi injection port. Mass selection between the FA and the SIFT is accomplished using a quadrupole mass spectrometer operating at a pressure of about $1 \times 10^{-5}$ torr. The SIFT flow gas was either helium or nitrogen that was scrubbed by passing the 
gas over liquid-nitrogen cooled molecular sieve material for helium, or dry ice-acetone cooled for nitrogen. The pressure was about 0.48 torr in the SIFT for helium and 0.2 torr for nitrogen. The flow times for an ion were about $6 \mathrm{~ms}$ from the Venturi entrance to their exit at the skimmer-nose-cone of the downstream end of the $95 \mathrm{~cm}$ SIFT flow tube. Small flows of reactant gases were added downstream from the Venturi orifice, $50.4 \mathrm{~cm}$ before the nose cone. Sampling of the ions in the SIFT was accomplished using a small orifice in a nose cone at the downstream end protruding into the flow tube, behind which was a second quadrupole mass filter. A particle multiplier with pulse counting technology was used to measure the ion abundances.

Gases were obtained commercially and purified using freeze-pump-thaw cycles, except the diacetylene which was prepared in the laboratory.

\section{Results}

The main experiments centered on the analysis of the eight pure hydrocarbon systems: Methane, acetylene, ethylene, ethane, propyne, propene, propane, and diacetylene. Mass spectra were taken at many pressures for each system. In addition, each mass spectrum was analyzed using both the double resonance ejection and the modulated double resonance ejection technique to identify the precursor ions and the product ions generated from them in subsequent reactions. The peak heights of all ions were then compared with the heights calculated using the set of reported literature reactions. Where differences occurred, subsequent experiments were conducted to either validate the differences or discard them. If new branching ratios were required they were measured carefully under specially designed conditions to maximize their accuracy. New reaction rate coefficients were also measured when they were needed. The resulting list of the kinetics determined in the ICR study is given in Table 1, along with literature values where available, for comparison. In the text, other tables are used to compare the JPL-ICR results with the University of Canterbury-SIFT results and they also show the enthalpy of the reactions.

Each set of ICR pressure studies was modeled from the list of reactions in Table 1. The partial differential equations for individual reactions were written down and the set of equations applicable to each binary system was solved for the exact solution for each ion in the spectrum. Individual reaction rate coefficients and branching ratios were determined relative to the reaction rate coefficient of one of the reactant ions through least-squared fitting of each system. The modeled data was compared to the experimental data and the leastsquares fit parameters were compared with the literature values. Where differences were found, the adjustable parameters were varied, and the modeled reactions were altered until a self-consistent data set was found. It is this self-consistent data set that is summarized in the rate coefficients and branching ratios that are listed in Table 1.

Two mechanisms were observed for association in some reactions in the ICR cell. One of these mechanisms has bimolecular kinetics and a radiative mechanism is assumed to be responsible for stabilization of the complex. The other mechanism has termolecular kinetics and in this case the association complex is stabilized by collisions with the bath gas. These two mechanisms are distinguished in the chemical equations by indicating the participation of the bath gas $\mathrm{M}$, in the stabilizing process. The rate coefficients for bimolecular reactions are designated by $k$, and those for termolecular reactions are designated by $\mathrm{k}_{3}$. In the SIFT, all the termolecular association reactions appear as saturated or close to saturated bimolecular reactions and we have assigned pseudobimolecular rate coefficients to these. These pseudo-bimolecular rate coefficients provide lower limits for the termolecular $\mathrm{k}_{3}$ (SIFT) coefficients. It is understood that these termolecular reaction rate coefficients were not obtained by a proper pressure study to examine their linear behavior with the buffer gas pressure. The pseudo-bimolecular rate coefficients only indicate the lower limit for the three-body reaction rate coefficient. We have assumed that there is a three-body channel in those cases in the SIFT, because the channel forms the adduct ion and there is evidence in the ICR that the channel is not the result of a radiative association process.

It is noted below that at times, significant differences exist between the measured reaction rate coefficients and branching ratios determined from fitting the models to the experimental data and the literature values of the thermal reactions. In Table 1 the secondary and high order ions are noted to be non-thermal by use of the parentheses and asterisk.

\section{Discussion}

\section{A. Reactions in Pure Methane}

In pure methane in the ICR both the methyl and methane ions were formed as primary ions. The reaction of both of these ions have been studied and reported on extensively in the literature already [10]. Our work supports these earlier results. Figure 1 shows that at pressures as high as 40 microns no reactions were detected from the $\mathrm{C}_{2} \mathrm{H}_{5}^{+}$and $\mathrm{CH}_{5}^{+}$ions. In Figure 1 the simplicity of the system can be seen. The mass 16 ion reacts to form the mass 17 ion and the mass 15 ion reacts to form the mass 29 ion. At 40 microns, only the primary reactions are seen.

\section{B. Reactions in Pure Acetylene}

In this sytem three consecutive reactions are observed in the pressure range up to 10 microns. In Figure 2 it is seen that nine different ion abundances were followed. This is one of the more complicated systems presented here. 
Table 1. Summary of reactions and rate coefficients used to model the ICR experimental results

\begin{tabular}{|c|c|c|c|c|}
\hline Reaction & & $\begin{array}{l}\text { Branching } \\
\text { ratio }\end{array}$ & $\begin{array}{l}\text { Reaction rate } \\
\text { coefficient }\end{array}$ & $\begin{array}{l}\text { Literature } \\
\text { value }^{\mathrm{b}}\end{array}$ \\
\hline \multicolumn{5}{|c|}{ Reactions in the pure methane system } \\
\hline $\begin{array}{l}\mathrm{CH}_{3}^{+}+\mathrm{CH}_{4} \\
\mathrm{CH}_{4}^{+}+\mathrm{CH}_{4}\end{array}$ & $\begin{array}{l}\rightarrow \mathrm{C}_{2} \mathrm{H}_{5}^{+}+\mathrm{H}_{2} \\
\rightarrow \mathrm{CH}_{5}^{+}+\mathrm{CH}_{3}\end{array}$ & & $\begin{array}{l}1.1 \times 10^{-9} \\
\left(1.1 \times 10^{-9}\right)^{c}\end{array}$ & $\begin{array}{l}1.1 \times 10^{-9} \\
1.1 \times 10^{-9}\end{array}$ \\
\hline \multicolumn{5}{|c|}{ Reactions in the pure acetylene system } \\
\hline $\mathrm{C}_{2} \mathrm{H}_{2}^{+}+\mathrm{C}_{2} \mathrm{H}_{2}$ & $\begin{array}{l}\rightarrow \mathrm{C}_{4} \mathrm{H}_{2}^{+}+\mathrm{H}_{2} \\
\rightarrow \mathrm{C}_{4} \mathrm{H}_{3}^{+}+\mathrm{H}\end{array}$ & $\begin{array}{l}0.32^{\text {cd }} \\
0.68^{\text {cd }}\end{array}$ & $\left(1.4 \times 10^{-9}\right)^{\mathrm{c}}$ & $1.4 \times 10^{-9}$ \\
\hline$\left(\mathrm{C}_{4} \mathrm{H}_{2}^{+}\right)^{*}+\mathrm{C}_{2} \mathrm{H}_{2}$ & $\begin{array}{l}\rightarrow \mathrm{C}_{6} \mathrm{H}_{3}^{+}+\mathrm{H} \\
\rightarrow \mathrm{C}_{6} \mathrm{H}_{4}^{+}\end{array}$ & $\begin{array}{l}0.17^{\mathrm{d}}(0.05)^{\mathrm{a}} \\
0.83^{\mathrm{d}}(0.95)^{\mathrm{a}}\end{array}$ & $1.6 \times 10^{-10}$ & $2.8 \times 10^{-10}$ \\
\hline \multirow{2}{*}{$\begin{array}{l}\left(\mathrm{C}_{4} \mathrm{H}_{2}{ }^{+}\right)^{*}+\mathrm{C}_{2} \mathrm{H}_{2}+\mathrm{C}_{2} \mathrm{H}_{2} \\
\left(\mathrm{C}_{4} \mathrm{H}_{3}{ }^{+}\right)^{*}+\mathrm{C}_{2} \mathrm{H}_{2}\end{array}$} & $\rightarrow \mathrm{C}_{6} \mathrm{H}_{4}^{+}+\mathrm{C}_{2} \mathrm{H}_{2}$ & 1.0 & $3.0 \times 10^{-24}$ & $5.7 \times 10^{-23 e}$ \\
\hline & $\begin{array}{l}\rightarrow \mathrm{C}_{6} \mathrm{H}_{4}^{+}+\mathrm{H} \\
\rightarrow \mathrm{C}_{6} \mathrm{H}_{5}^{+}\end{array}$ & $\begin{array}{l}0.00^{\mathrm{c}} \\
1.00^{\mathrm{c}}(1.0)^{\mathrm{a}}\end{array}$ & $3.5 \times 10^{-11}$ & $2.2 \times 10^{-10}$ \\
\hline \multirow{6}{*}{$\begin{array}{l}\left(\mathrm{C}_{4} \mathrm{H}_{3}^{+}\right)^{*}+\mathrm{C}_{2} \mathrm{H}_{2}+\mathrm{C}_{2} \mathrm{H}_{2} \\
\left(\mathrm{C}_{6} \mathrm{H}_{3}^{+}\right)^{*}+\mathrm{C}_{2} \mathrm{H}_{2} \\
\left(\mathrm{C}_{6} \mathrm{H}_{4}^{+}\right)^{*}+\mathrm{C}_{2} \mathrm{H}_{2} \\
\left(\mathrm{C}_{6} \mathrm{H}_{5}^{+}\right)^{*}+\mathrm{C}_{2} \mathrm{H}_{2} \\
\left(\mathrm{C}_{8} \mathrm{H}_{6}^{+}\right)^{*}+\mathrm{C}_{2} \mathrm{H}_{2} \\
\left(\mathrm{C}_{8} \mathrm{H}_{7}^{+}\right)^{*}+\mathrm{C}_{2} \mathrm{H}_{2}\end{array}$} & $\rightarrow \mathrm{C}_{6} \mathrm{H}_{5}^{+}+\mathrm{C}_{2} \mathrm{H}_{2}$ & 1.0 & $6.2 \times 10^{-24}$ & $1.3 \times 10^{-23 \mathrm{e}}$ \\
\hline & $\rightarrow \mathrm{C}_{8} \mathrm{H}_{5}^{+}$ & 1.0 & $4.6 \times 10^{-10}$ & \\
\hline & $\rightarrow \mathrm{C}_{8} \mathrm{H}_{6}^{+}$ & 1.0 & $2.8 \times 10^{-11}$ & \\
\hline & $\rightarrow \mathrm{C}_{8} \mathrm{H}_{7}^{+}$ & 1.0 & $2.5 \times 10^{-11}$ & $4.0 \times 10^{-10}$ \\
\hline & $\rightarrow \mathrm{C}_{10} \mathrm{H}_{8}^{+}$ & & $<1.0 \times 10^{-12}$ & \\
\hline & $\rightarrow \mathrm{C}_{10} \mathrm{H}_{9}^{+}$ & & $<1.0 \times 10^{-12}$ & \\
\hline \multicolumn{5}{|c|}{ Reactions in the pure ethylene system } \\
\hline $\mathrm{C}_{2} \mathrm{H}_{4}^{+}+\mathrm{C}_{2} \mathrm{H}_{4}$ & $\begin{array}{l}\rightarrow \mathrm{C}_{3} \mathrm{H}_{5}^{+}+\mathrm{CH}_{3} \\
\rightarrow \mathrm{C}_{4} \mathrm{H}_{7}^{+}+\mathrm{H}\end{array}$ & $\begin{array}{l}0.93(0.91)^{\mathrm{a}} \\
0.07(0.09)^{\mathrm{a}}\end{array}$ & $\left(7.9 \times 10^{-10}\right)^{c}$ & $8.3 \times 10^{-10}$ \\
\hline$\left(\mathrm{C}_{3} \mathrm{H}_{5}{ }^{+}\right)^{*}+\mathrm{C}_{2} \mathrm{H}_{4}$ & $\rightarrow \mathrm{C}_{5} \mathrm{H}_{7}^{+}+\mathrm{H}_{2}$ & 1.0 & $7.7 \times 10^{-11}$ & $1.2 \times 10^{-10}$ \\
\hline$\left(\mathrm{C}_{3} \mathrm{H}_{5}\right)^{*}+\mathrm{C}_{2} \mathrm{H}_{4}+\mathrm{C}_{2} \mathrm{H}_{4}$ & $\rightarrow \mathrm{C}_{5} \mathrm{H}_{9}^{+}+\mathrm{C}_{2} \mathrm{H}_{4}$ & 1.0 & $1.6 \times 10^{-23}$ & \\
\hline$\left(\mathrm{C}_{4} \mathrm{H}_{7}^{+}\right)^{*}+\mathrm{C}_{2} \mathrm{H}_{4}$ & $\rightarrow$ no reaction & & $<2.0 \times 10^{-11}$ & \\
\hline$\left(\mathrm{C}_{4} \mathrm{H}_{7}^{+}\right)^{*}+\mathrm{C}_{2} \mathrm{H}_{4}+\mathrm{C}_{2} \mathrm{H}_{4}$ & $\rightarrow \mathrm{C}_{6} \mathrm{H}_{11}{ }^{+}+\mathrm{C}_{2} \mathrm{H}_{4}$ & 1.0 & $1.4 \times 1.0^{-24}$ & \\
\hline \multicolumn{5}{|c|}{ Reactions in the pure ethane system } \\
\hline $\mathrm{C}_{2} \mathrm{H}_{4}^{+}+\mathrm{C}_{2} \mathrm{H}_{6}$ & $\begin{array}{l}\rightarrow \mathrm{C}_{3} \mathrm{H}_{6}^{+}+\mathrm{CH}_{4} \\
\rightarrow \mathrm{C}_{3} \mathrm{H}_{7}^{+}+\mathrm{CH}_{3}\end{array}$ & $\begin{array}{l}0.00(0.07)^{\mathrm{a}} \\
1.00(0.93)^{\mathrm{a}}\end{array}$ & $8.0 \times 10^{-12}$ & $5.2 \times 10^{-12}$ \\
\hline $\mathrm{C}_{2} \mathrm{H}_{6}{ }^{+}+\mathrm{C}_{2} \mathrm{H}_{6}$ & $\begin{array}{l}\rightarrow \mathrm{C}_{3} \mathrm{H}_{8}^{+}+\mathrm{CH}_{4} \\
\rightarrow \mathrm{C}_{3} \mathrm{H}_{9}^{+}+\mathrm{CH}_{3} \\
\rightarrow \mathrm{C}_{4} \mathrm{H}_{9}^{+}+\mathrm{H}_{2}+\mathrm{H} \\
\text { oyne system }\end{array}$ & $\begin{array}{l}0.23(0.42)^{\mathrm{a}} \\
0.00(0.58)^{\mathrm{a}} \\
0.77(0.00)^{\mathrm{a}}\end{array}$ & $2.1 \times 10^{-11}$ & $1.9 \times 10^{-11}$ \\
\hline \multirow{5}{*}{$\begin{array}{l}\mathrm{C}_{3} \mathrm{H}_{3}^{+}+\mathrm{C}_{3} \mathrm{H}_{4} \\
\mathrm{C}_{3} \mathrm{H}_{4}^{+}+\mathrm{C}_{3} \mathrm{H}_{4}\end{array}$} & $\rightarrow$ no reaction & 0.0 & $\leq 1.0 \times 10^{-11}$ & \\
\hline & $\rightarrow \mathrm{C}_{3} \mathrm{H}_{5}^{+}+\mathrm{C}_{3} \mathrm{H}_{3}$ & $0.21(0.18)^{a}$ & $\left(1.1 \times 10^{-9}\right)^{\mathrm{c}}$ & $1.1 \times 10^{-9}$ \\
\hline & $\rightarrow \mathrm{C}_{6} \mathrm{H}_{5}^{+}+\mathrm{H}_{2}+\mathrm{H}$ & $0.14(0.08)^{\mathrm{a}}$ & & \\
\hline & $\rightarrow \mathrm{C}_{6} \mathrm{H}_{7}^{+} \mathrm{a}+\mathrm{H}$ & $0.38(0.30)^{a}$ & & \\
\hline & $\rightarrow \mathrm{C}_{6} \mathrm{H}_{7}^{+} \mathrm{b}+\mathrm{H}$ & $0.27(0.38)^{a}$ & & \\
\hline \multirow{2}{*}{$\begin{array}{l}\mathrm{C}_{3} \mathrm{H}_{5}{ }^{+}+\mathrm{C}_{3} \mathrm{H}_{4} \\
\left(\mathrm{C}_{6} \mathrm{H}_{5}{ }^{+}\right)^{*}+\mathrm{C}_{3} \mathrm{H}_{4}\end{array}$} & $\rightarrow \mathrm{C}_{6} \mathrm{H}_{7}^{+}+\mathrm{H}_{2}$ & 1.0 & $3.5 \times 1.0^{-10}$ & \\
\hline & $\rightarrow \mathrm{C}_{7} \mathrm{H}_{7}^{+}+\mathrm{C}_{2} \mathrm{H}_{2}$ & $0.70(0.18)^{\mathrm{a}}$ & $5.8 \times 10^{-11}$ & $2.3 \times 10^{-10}$ \\
\hline & $\rightarrow \mathrm{C}_{9} \mathrm{H}_{7}^{+}+\mathrm{H}_{2}$ & $0.30(0.78)^{a}$ & & \\
\hline \multirow{3}{*}{\multicolumn{2}{|c|}{$\begin{aligned} &\left(\mathrm{C}_{6} \mathrm{H}_{5}{ }^{+}\right) \mathrm{a}^{*}+\mathrm{C}_{3} \mathrm{H}_{4}+\mathrm{C}_{3} \mathrm{H}_{4} \rightarrow \mathrm{C}_{9} \mathrm{H}_{9}^{+}+\mathrm{C}_{3} \mathrm{H}_{4} \\
&\left(\mathrm{C}_{6} \mathrm{H}_{7}^{+}\right) \mathrm{a}^{*}+\mathrm{C}_{3} \mathrm{H}_{4} \rightarrow \mathrm{C}_{7} \mathrm{H}_{7}^{+}+\mathrm{C}_{2} \mathrm{H}_{4} \\
&\left(\mathrm{C}_{6} \mathrm{H}_{7}^{+}\right) \mathrm{a}^{*}+\mathrm{C}_{3} \mathrm{H}_{4}+\mathrm{C}_{3} \mathrm{H}_{4} \rightarrow \mathrm{C}_{9} \mathrm{H}_{11}^{+}\end{aligned}$}} & 1.0 & $5.2 \times 10^{-24}$ & \\
\hline & & 1.0 & $5.6 \times 10^{-11}$ & \\
\hline & & 1.0 & $5.2 \times 10^{-25}$ & \\
\hline \multirow{5}{*}{$\begin{array}{l}\left(\mathrm{C}_{7} \mathrm{H}_{7}^{+}\right) \mathrm{a}^{*}+\mathrm{C}_{3} \mathrm{H}_{4} \\
\left(\mathrm{C}_{7} \mathrm{H}_{7}^{+}\right) \mathrm{b}^{*}+\mathrm{C}_{3} \mathrm{H}_{4} \\
\left(\mathrm{C}_{7} \mathrm{H}_{7}^{+}\right) \mathrm{a}^{*}+\mathrm{C}_{3} \mathrm{H}_{4}+\mathrm{C}_{3} \mathrm{H}_{2} \\
\left(\mathrm{C}_{9} \mathrm{H}_{7}^{+}\right)^{*}+\mathrm{C}_{3} \mathrm{H}_{4} \\
\left(\mathrm{C}_{9} \mathrm{H}_{7}^{+}\right)^{*}+\mathrm{C}_{3} \mathrm{H}_{4}+\mathrm{C}_{3} \mathrm{H}_{4}\end{array}$} & $\rightarrow \mathrm{C}_{10} \mathrm{H}_{9}^{+}+\mathrm{H}_{2}$ & 1.0 & $1.9 \times 10^{-11}$ & \\
\hline & $\rightarrow$ no reaction & & $\leq 5.0 \times 10^{-13}$ & \\
\hline & ${ }_{4} \rightarrow \mathrm{C}_{10} \mathrm{H}_{11}^{+}$ & & $\leq 3.7 \times 10^{-24}$ & \\
\hline & $\rightarrow$ no reaction & & $\leq 2.0 \times 10^{-11}$ & \\
\hline & $\rightarrow$ no reaction & & $\leq 1.0 \times 10^{-25}$ & \\
\hline \multicolumn{5}{|c|}{ Reactions in the pure propene system } \\
\hline \multirow{5}{*}{$\begin{array}{l}\mathrm{C}_{3} \mathrm{H}_{5}^{+}+\mathrm{C}_{3} \mathrm{H}_{6} \\
\mathrm{C}_{3} \mathrm{H}_{6}^{+}+\mathrm{C}_{3} \mathrm{H}_{6}\end{array}$} & $\rightarrow \mathrm{C}_{4} \mathrm{H}_{7}^{+}+\mathrm{C}_{2} \mathrm{H}_{4}$ & 1.0 & $1.0 \times 10^{-9}$ & \\
\hline & $\rightarrow \mathrm{C}_{3} \mathrm{H}_{7}^{+}+\mathrm{C}_{3} \mathrm{H}_{5}$ & $0.18(0.15)^{a}$ & $1.4 \times 10^{-9}$ & $1.4 \times 10^{-9}$ \\
\hline & $\rightarrow \mathrm{C}_{4} \mathrm{H}_{7}^{+}+\mathrm{C}_{2} \mathrm{H}_{5}$ & $0.11(0.20)^{\mathrm{a}}$ & & \\
\hline & $\rightarrow \mathrm{C}_{4} \mathrm{H}_{8}{ }^{+}+\mathrm{C}_{2} \mathrm{H}_{4}$ & $0.40(0.35)^{\mathrm{a}}$ & & \\
\hline & $\rightarrow \mathrm{C}_{5} \mathrm{H}_{9}^{+}+\mathrm{CH}_{3}$ & $0.32(0.30)^{a}$ & & \\
\hline \multirow{4}{*}{$\begin{array}{l}\left(\mathrm{C}_{3} \mathrm{H}_{7}^{+}\right)^{*}+\mathrm{C}_{3} \mathrm{H}_{6} \\
\left(\mathrm{C}_{4} \mathrm{H}_{7}^{+}\right)^{*}+\mathrm{C}_{3} \mathrm{H}_{6} \\
\left(\mathrm{C}_{4} \mathrm{H}_{8}^{+}\right)^{*}+\mathrm{C}_{3} \mathrm{H}_{6}\end{array}$} & $\rightarrow \mathrm{C}_{4} \mathrm{H}_{9}^{+}+\mathrm{C}_{2} \mathrm{H}_{4}$ & 1.0 & $4.5 \times 10^{-10}$ & \\
\hline & $\rightarrow \mathrm{C}_{5} \mathrm{H}_{9}^{+}+\mathrm{C}_{2} \mathrm{H}_{4}$ & 1.0 & $5.6 \times 10^{-11}$ & \\
\hline & $\rightarrow \mathrm{C}_{4} \mathrm{H}_{9}{ }^{+}+\mathrm{C}_{3} \mathrm{H}_{5}$ & 0.24 & $8.6 \times 10^{-11}$ & \\
\hline & $\rightarrow \mathrm{C}_{5} \mathrm{H}_{10}{ }^{+}+\mathrm{C}_{2} \mathrm{H}_{4}$ & 0.76 & & \\
\hline Reactions in the pure prop & bane system & & & \\
\hline $\mathrm{C}_{2} \mathrm{H}_{4}^{+}+\mathrm{C}_{3} \mathrm{H}_{8}$ & $\rightarrow \mathrm{C}_{3} \mathrm{H}_{6}^{+}+\mathrm{C}_{2} \mathrm{H}_{6}$ & 0.52 & $9.4 \times 10^{-10}$ & \\
\hline & $\rightarrow \mathrm{C}_{3} \mathrm{H}_{7}^{+}+\mathrm{C}_{2} \mathrm{H}_{5}$ & 0.48 & & \\
\hline $\mathrm{C}_{2} \mathrm{H}_{5}{ }^{+}+\mathrm{C}_{3} \mathrm{H}_{8}$ & $\rightarrow \mathrm{C}_{3} \mathrm{H}_{7}^{+}+\mathrm{C}_{2} \mathrm{H}_{6}$ & 1.0 & $4.8 \times 10^{-10}$ & \\
\hline $\mathrm{C}_{3} \mathrm{H}_{6}^{+}+\mathrm{C}_{3} \mathrm{H}_{8}$ & $\rightarrow$ no reaction & & $\leq 3.0 \times 10^{-12}$ & \\
\hline $\mathrm{C}_{3} \mathrm{H}_{7}^{+}+\mathrm{C}_{3} \mathrm{H}_{8}$ & $\rightarrow$ no reaction & & $\leq 3.0 \times 10^{-12}$ & \\
\hline $\mathrm{C}_{3} \mathrm{H}_{8}^{+}+\mathrm{C}_{3} \mathrm{H}_{8}$ & $\rightarrow$ no reaction & & $\leq 3.0 \times 10^{-12}$ & \\
\hline
\end{tabular}


Table 1. Summary of reactions and rate coefficients used to model the ICR experimental results

\begin{tabular}{llll}
\hline Reaction & & $\begin{array}{c}\text { Branching } \\
\text { ratio }\end{array}$ & $\begin{array}{c}\text { Reaction rate } \\
\text { coefficient }\end{array}$ \\
\hline \hline Reactions in the pure diacetylene system & & \\
$\mathrm{C}_{4} \mathrm{H}_{2}^{+}+\mathrm{C}_{4} \mathrm{H}_{2}$ & $\rightarrow \mathrm{C}_{6} \mathrm{H}_{2}^{+}+\mathrm{C}_{2} \mathrm{H}_{2}$ & 1.0 & $1.4 \times 10^{-9}$ \\
$\left(\mathrm{C}_{6} \mathrm{H}_{2}^{+}\right)^{*}+\mathrm{C}_{4} \mathrm{H}_{2}$ & $\rightarrow \mathrm{C}_{8} \mathrm{H}_{2}^{+}+\mathrm{C}_{2} \mathrm{H}_{2}$ & 1.0 & $6.7 \times 10^{-10}$ \\
$\left(\mathrm{C}_{6} \mathrm{H}_{2}^{+}\right)^{*}+\mathrm{C}_{4} \mathrm{H}_{2}+\mathrm{C}_{4} \mathrm{H}_{2}$ & $\rightarrow \mathrm{C}_{10} \mathrm{H}_{4}^{+}$ & 1.0 & $3.4 \times 10^{-23}$ \\
$\left(\mathrm{C}_{8} \mathrm{H}_{2}^{+}\right)^{*}+\mathrm{C}_{4} \mathrm{H}_{2}+\mathrm{C}_{4} \mathrm{H}_{2}$ & $\rightarrow \mathrm{C}_{12} \mathrm{H}_{4}^{+}$ & 1.0 & $6.2 \times 10^{-23}$ \\
\hline
\end{tabular}

$a=$ reactive form; $b=$ unreactive form

${ }^{a}$ Branching ratios are taken from Anicich and McEwan (1997).

bLiterature rate coefficients are taken from the compilation of Anicich and McEwan, 1997, unless specified otherwise.

${ }^{\mathrm{c}}$ The reaction rate coefficients in brackets are the literature rate coefficients for the listed reaction. All other reaction rate coefficients are determined relative to this reaction.

dThe branching ratio changes with pressure. See text.

eAnicich et al., 1990.

fThe reactive form of $\mathrm{C}_{6} \mathrm{H}_{5}{ }^{+}$has been identified as the cyclic isomer.

ICR/SIFT Table

$$
\mathrm{C}_{2} \mathrm{H}_{2}^{+}+\mathrm{C}_{2} \mathrm{H}_{2}
$$

\begin{tabular}{lll} 
ICR & SIFT & $\Delta \mathrm{H}(\mathrm{kJ} / \mathrm{mol})$. \\
\hline 0.32 & 0.47 & -107.2 \\
0.68 & 0.53 & -78.5
\end{tabular}

$$
\begin{aligned}
& k(I C R)=1.4 \times 10^{-9} \mathrm{~cm}^{3} \mathrm{~s}^{-1} \\
& k(\mathrm{SIFT})=1.4 \times 10^{-9} \mathrm{~cm}^{3} \mathrm{~s}^{-1} \text { in } 0.5 \text { Torr of He }
\end{aligned}
$$

The $\mathrm{C}_{2} \mathrm{H}_{2}^{+}+\mathrm{C}_{2} \mathrm{H}_{2}$ reaction and subsequent reactions of products with $\mathrm{C}_{2} \mathrm{H}_{2}$ were followed up to the formation of $\mathrm{C}_{8}$ compounds. These results are summarized in this section on the pure acetylene system. Results for individual ion reactions with $\mathrm{C}_{2} \mathrm{H}_{2}$ were obtained and these data follow. The reaction rate coefficient for Reaction (B1) was taken from previous work [10] and is used here as a calibration for the other reaction rate coefficients measured. However in this study the branching ratio for Reaction (B1) had to vary in order to fit the data set over the pressure

Methane

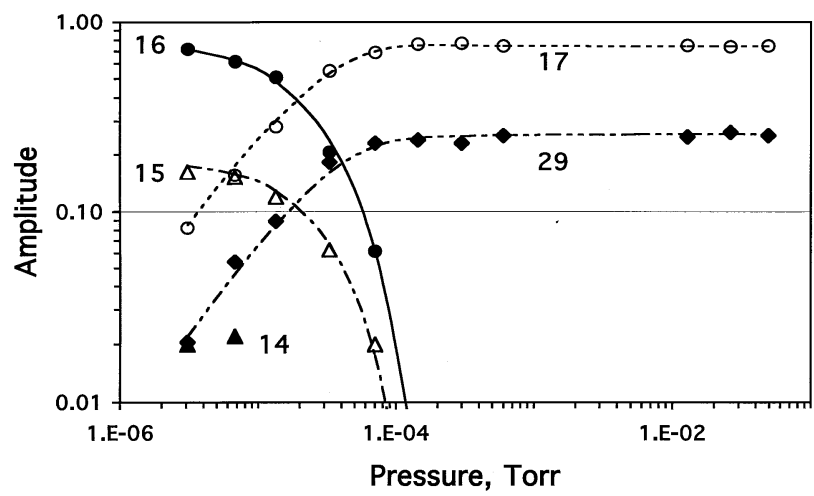

Figure 1. Variation of ion density with pressure in the ICR cell from pure methane. The points are experimental and the curves are the model fit derived from the kinetic data described in the text. The numbers next to the data and the curves are the $\mathrm{m} / \mathrm{z}$ of the ions followed. range of $10^{-5}$ to $10^{-2}$ torr. The branching ratio reported above is for the lowest pressure of $3 \times 10^{-6}$ torr. At the maximum pressure of the study the branching ratio was 0.58 for the $\mathrm{C}_{4} \mathrm{H}_{2}^{+}$channel. A model was used to smoothly change the branching ratio using the collision frequency as the independent variable. We emphasize again that it was only possible to obtain a fit to the data with the model when the branching ratio was varied. This change in branching ratio is consistent with the data reported using the SIFT at much higher pressures [11].

\section{Acetylene}

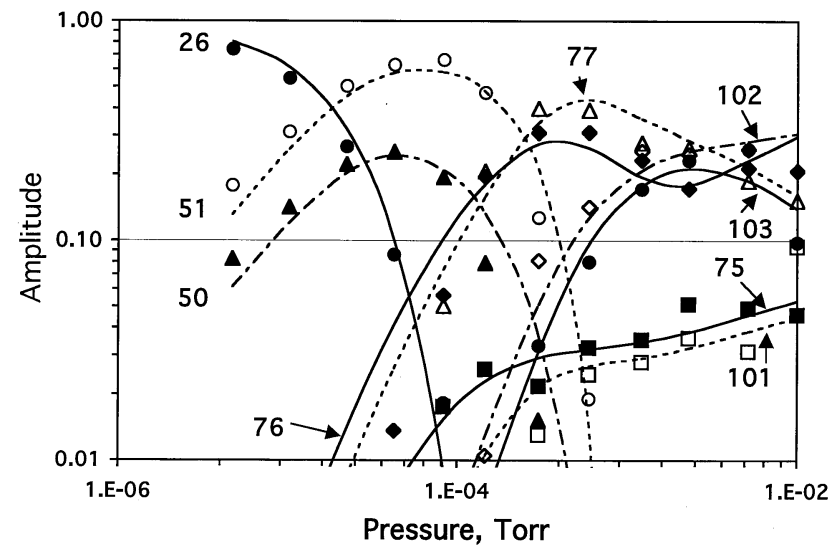

Figure 2. Variation of ion density with pressure in the ICR cell from pure acetylene. The points are experimental and the curves are the model fit derived from the kinetic data described in the text. The numbers next to the data and the curves are the $m / z$ of the ions followed. 


$$
\begin{aligned}
& \left(\mathrm{C}_{4} \mathrm{H}_{2}{ }^{+}\right)^{*}+\mathrm{C}_{2} \mathrm{H}_{2} \\
& \rightarrow \mathrm{C}_{6} \mathrm{H}_{3}^{+}+\mathrm{H} \\
& \rightarrow \mathrm{C}_{6} \mathrm{H}_{4}^{+} \\
& \begin{array}{lll}
\text { ICR } & \text { SIFT } & \Delta \mathrm{H}(\mathrm{kJ} / \mathrm{mol} .) \\
\hline 0.17 & & -364.9
\end{array} \\
& 0.83 \quad-361.9 \\
& k_{2}(I C R)=1.6 \times 10^{-10} \mathrm{~cm}^{3} \mathrm{~s}^{-1} \\
& \mathrm{C}_{4} \mathrm{H}_{2}^{+}+\mathrm{C}_{2} \mathrm{H}_{2}+\mathrm{M} \\
& \rightarrow \mathrm{C}_{6} \mathrm{H}_{4}^{+}+\mathrm{M} \\
& \begin{array}{lll}
(1.0) & 1.0 \quad-361.9
\end{array} \\
& k_{3}(I C R)=3.0 \times 10^{-24} \mathrm{~cm}^{6} \mathrm{~s}^{-1}\left(\mathrm{M}=\mathrm{C}_{2} \mathrm{H}_{2}\right) \\
& k(\mathrm{SIFT})=1.1 \times 10^{-9} \mathrm{~cm}^{3} \mathrm{~s}^{-1} \text { in } 0.5 \text { Torr of He } \\
& \mathrm{k}_{3}(\mathrm{SIFT}) \geq 8.0 \times 10^{-26} \mathrm{~cm}^{6} \mathrm{~s}^{-1}(\mathrm{M}=\mathrm{He})
\end{aligned}
$$

The ICR reaction rate coefficients reported here are much smaller than the rate coefficients reported in previous measurements because the $\mathrm{C}_{4} \mathrm{H}_{2}^{+}$ions in the acetylene system are made by the exothermic Reaction (B1). These excited ions do not have time in the ICR to lose their internal energy. This effect has been discussed in some detail by Anicich, et al. [12]. Although part of this energy may be electronic it is expected that in the time scale of an ICR experiment, most of the energy is in the form of vibrational excitation that is only slowly removed by collisions with the bath gas. Ions formed via ion-molecule reactions and that are known to have excess internal energy are designated $\mathrm{C}_{4} \mathrm{H}_{2}^{+*}$. The excess internal energy in the reactant ion slows the reactions and makes the association channel less probable. A similar situation to the varying branching ratio measured for the $\mathrm{C}_{2} \mathrm{H}_{2}^{+} / \mathrm{C}_{2} \mathrm{H}_{2}$ reaction is observed for $\mathrm{C}_{4} \mathrm{H}_{2}^{+}$ in Reaction (B2). Here, the branching ratio changes over the pressure range of $10^{-5}$ to $10^{-2}$ torr from the reported value for the production of $\mathrm{C}_{6} \mathrm{H}_{3}^{+}$above at the lowest pressure of 0.17 (i.e., highest energy), to 0.60 at the highest pressure. This effect is counter intuitive, as it might be expected that more energy is taken out of the complex and reactant ion in collisions with the bath gas at higher pressures. Therefore, the bimolecular association channel should become more prominent as the

$$
\begin{aligned}
& \left(\mathrm{C}_{4} \mathrm{H}_{3}^{+}\right)^{*}+\mathrm{C}_{2} \mathrm{H}_{2} \quad \rightarrow \mathrm{C}_{6} \mathrm{H}_{4}^{+}+\mathrm{H} \\
& \begin{array}{l}
\rightarrow \mathrm{C}_{6} \mathrm{H}_{5}^{+} \\
\mathrm{k}(\mathrm{ICR})=3.5 \times 10^{-11} \mathrm{~cm}^{3} \mathrm{~s}^{-1}
\end{array} \\
& \begin{array}{l}
\rightarrow \mathrm{C}_{6} \mathrm{H}_{5}^{+} \\
\mathrm{k}(\mathrm{ICR})=3.5 \times 10^{-11} \mathrm{~cm}^{3} \mathrm{~s}^{-1}
\end{array} \\
& \mathrm{C}_{4} \mathrm{H}_{3}^{+}+\mathrm{C}_{2} \mathrm{H}_{2}+\mathrm{M} \quad \rightarrow \mathrm{C}_{6} \mathrm{H}_{5}^{+}+\mathrm{M} \quad 1.0 \quad 1.0 \quad-348 . \\
& \mathrm{C}_{4} \mathrm{H}_{3}^{+}+\mathrm{C}_{2} \mathrm{H}_{2}+\mathrm{M} \quad \rightarrow \mathrm{C}_{6} \mathrm{H}_{5}^{+}+\mathrm{M} \quad 1.0 \quad 1.0 \quad-348 .
\end{aligned}
$$

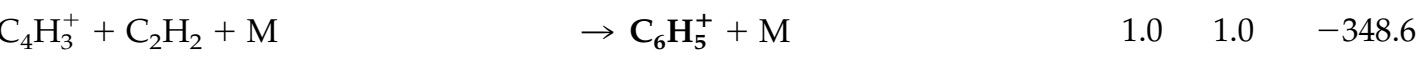

$$
\begin{aligned}
& \begin{array}{lcc}
\text { ICR } & \text { SIFT } & \Delta \mathrm{H}(\mathrm{kJ} / \mathrm{mol} .) \\
\hline 0.0 & 6.2 \\
1.0 & -348.6
\end{array} \\
& \begin{array}{l}
k_{3}(I C R)=6.2 \times 10^{-24} \mathrm{~cm}^{6} \mathrm{~s}^{-1}\left(\mathrm{M}=\mathrm{C}_{2} \mathrm{H}_{2}\right) \\
k(\mathrm{SIFT})=8.3 \times 10^{-10} \mathrm{~cm}^{3} \mathrm{~s}^{-1} \text { in } 0.5 \text { Torr of He } \\
k_{3}(\mathrm{SIFT}) \geq 8.0 \times 10^{-26} \mathrm{~cm}^{6} \mathrm{~s}^{-1}(\mathrm{M}=\mathrm{He})
\end{array} \\
& \begin{array}{l}
k_{3}(I C R)=6.2 \times 10^{-24} \mathrm{~cm}^{6} \mathrm{~s}^{-1}\left(\mathrm{M}=\mathrm{C}_{2} \mathrm{H}_{2}\right) \\
k(\mathrm{SIFT})=8.3 \times 10^{-10} \mathrm{~cm}^{3} \mathrm{~s}^{-1} \text { in } 0.5 \text { Torr of He } \\
k_{3}(\mathrm{SIFT}) \geq 8.0 \times 10^{-26} \mathrm{~cm}^{6} \mathrm{~s}^{-1}(\mathrm{M}=\mathrm{He})
\end{array} \\
& \begin{array}{l}
k_{3}(I C R)=6.2 \times 10^{-24} \mathrm{~cm}^{6} \mathrm{~s}^{-1}\left(\mathrm{M}=\mathrm{C}_{2} \mathrm{H}_{2}\right) \\
k(\mathrm{SIFT})=8.3 \times 10^{-10} \mathrm{~cm}^{3} \mathrm{~s}^{-1} \text { in } 0.5 \text { Torr of He } \\
k_{3}(\mathrm{SIFT}) \geq 8.0 \times 10^{-26} \mathrm{~cm}^{6} \mathrm{~s}^{-1}(\mathrm{M}=\mathrm{He})
\end{array}
\end{aligned}
$$

pressure increases. Instead the reverse occurs. What seems to be happening here is a barrier in the reactant channel allows more complexes to dissociate at higher energies. As the complex is cooled, less dissociation to reactants occurs with a corresponding increase in the rate coefficient and the favorable reaction is the bimolecular channel to $\mathrm{C}_{6} \mathrm{H}_{3}^{+}$formation. Termolecular association occurs in competition with the bimolecular channels. As the pressure increases still further, the termolecular association reaction leading to association $\left(\mathrm{k}_{3}\right)$ takes over and becomes dominant as is evidenced by the SIFT results. The SIFT result appears as a pseudo-bimolecular rate coefficient but studies on numerous other associating systems show that it does in act follow termolecular kinetics. The lower limit for the cular rate coefficient is $k_{3}(\mathrm{SIFT}) \geq 8.0 \times$ $\mathrm{m}^{6}{ }^{-1}$ with $\mathrm{He}$ as the third body. Here almost all lead to an association product that is stabicase one is reactive and the other appare with $\mathrm{C}_{2} \mathrm{H}_{2}$. About $50 \%$ of the $\mathrm{C}_{6} \mathrm{H}_{3}^{+}$ion was found to be reactive and more than $80 \%$ of the $\mathrm{C}_{6} \mathrm{H}_{4}^{+}$ion was found to be reactive with acetylene.
The ICR reaction rate coefficients are much smaller than the values reported in previous measurements because the $\mathrm{C}_{4} \mathrm{H}_{3}^{+}$ions are made by an exothermic Reaction (B1) and these ions do not have time in the ICR to lose their internal energy received in their formation. The excess internal energy in the reactant ion slows the reactions 
and makes the association channel less probable. Also we found that the branching ratio for Reaction (B3) changes over the pressure range of $10^{-5}$ to $10^{-2}$ torr from the reported value above at the lowest pressure, to 0.96 for the production of $\mathrm{C}_{6} \mathrm{H}_{4}^{+}$at the highest pressure as was also observed in Reactions (B1) and (B2). The $\mathrm{C}_{6} \mathrm{H}_{4}^{+}$product ions of Reaction (B3) are each made in at least two different isomeric forms: one being reactive and the other apparently unreactive with $\mathrm{C}_{2} \mathrm{H}_{2}$. About $50 \%$ of the $\mathrm{C}_{6} \mathrm{H}_{4}^{+}$ion was found to be reactive. The endothermicity shown for Reactions (B3) of $6.2 \mathrm{~kJ} / \mathrm{mol}$ for the $\mathrm{C}_{6} \mathrm{H}_{4}^{+}+\mathrm{H}$ products, are within the uncertainty of being exothermic. A very similar situation exists here as occurs in Reaction (B2). As the pressure increases the reaction rate coefficient for $\mathrm{C}_{6} \mathrm{H}_{4}^{+}+\mathrm{H}$ increases, surpassing the bimolecular association channel to $\mathrm{C}_{6} \mathrm{H}_{5}^{+}$as the reaction barrier becomes less significant. At higher pressures still, the SIFT results show the termolecular association channel dominates with most collisions resulting in association.

$$
\begin{array}{ll}
\left(\mathrm{C}_{6} \mathrm{H}_{3}^{+}\right)^{*}+\mathrm{C}_{2} \mathrm{H}_{2} & \rightarrow \mathrm{C}_{8} \mathrm{H}_{5}^{+} \\
& \mathbf{k}(\mathrm{ICR})=4.6 \times 10^{-10} \mathrm{~cm}^{3} \mathrm{~s}^{-1} \\
\mathrm{C}_{6} \mathrm{H}_{3}^{+}+\mathrm{C}_{2} \mathrm{H}_{2}+\mathrm{M} & \rightarrow \mathrm{C}_{8} \mathrm{H}_{5}^{+}+\mathrm{M} \\
& \mathbf{k}(\mathrm{SIFT})=1.6 \times 10^{-10} \mathrm{~cm}^{3} \mathrm{~s}^{-1} \text { in } 0.5 \text { Torr of He } \\
& \mathbf{k}_{\mathbf{3}}(\mathrm{SIFT}) \geq \mathbf{9 . 9} \times 10^{-27} \mathrm{~cm}^{6} \mathrm{~s}^{-1}(\mathrm{M}=\mathrm{He})
\end{array}
$$$$
-361.7
$$

The $\mathrm{C}_{6} \mathrm{H}_{3}^{+}$ion in Reaction $\mathrm{B} 4$ was formed as a product of the exothermic Reaction (B2) and the reaction rate coefficient reported may be lower than that of the ground state ion. As noted earlier, two different structures of $\mathrm{C}_{6} \mathrm{H}_{3}^{+}$were produced in Reaction (B2): One was reactive with $\mathrm{C}_{2} \mathrm{H}_{2}$ and the other was unreactive. In $a$ mixture of methane and acetylene the reaction rate coefficient for Reaction B4 was determined to be $2.5 \times$

$$
\begin{array}{ll}
\left(\mathrm{C}_{6} \mathrm{H}_{4}^{+}\right)^{*}+\mathrm{C}_{2} \mathrm{H}_{2} & \rightarrow \mathrm{C}_{8} \mathrm{H}_{6}^{+} \\
& \mathbf{k}(\mathrm{ICR})=2.8 \times \mathbf{1 0}^{-11} \mathbf{c m}^{3} \mathrm{~s}^{-1} \\
\mathrm{C}_{6} \mathrm{H}_{4}^{+}+\mathrm{C}_{2} \mathrm{H}_{2}+\mathrm{M} & \rightarrow \mathrm{C}_{8} \mathrm{H}_{6}^{+}+\mathrm{M} \\
& \mathbf{k}(\mathrm{SIFT})=7.0 \times \mathbf{1 0}^{-11} \mathrm{~cm}^{3} \mathrm{~s}^{-1} \text { in } 0.5 \text { Torr of He } \\
& \mathbf{k}_{\mathbf{3}}(\mathrm{SIFT}) \geq 4.3 \times 10^{-27} \mathrm{~cm}^{6} \mathrm{~s}^{-1}(\mathrm{M}=\mathrm{He})
\end{array}
$$

The $\mathrm{C}_{6} \mathrm{H}_{4}^{+}$was formed by exothermic reactions in the acetylene system [(B2) and (B3)], the reaction rate coefficients observed in this study may be smaller than that for ground state ions. In a mixture of methane and acetylene the reaction rate coefficient was determined to be $6.0 \times$ $10^{-11} \mathrm{~cm}^{3} / \mathrm{s}$. The results in the methane mixture may be higher due to less internal energy in the association complex or just a consequence of a larger error in the$$
-381.7
$$

$10^{-10} \mathrm{~cm}^{3} / \mathrm{s}$. The results presented for Reaction (B4) may be higher than the methane mixture results due to less internal energy or because of larger errors in the determination. In the pure acetylene system the reaction rate coefficient was $4.6 \times 10^{-10} \mathrm{~cm}^{3} \mathrm{~s}^{-1}$ for bimolecular association from the reactive component of the $\mathrm{C}_{6} \mathrm{H}_{3}^{+}$ products. The reactive component amounted to about $50 \%$ of the total $\mathrm{C}_{6} \mathrm{H}_{3}^{+}$ions produced.

$\begin{array}{lll}\text { ICR } & \text { SIFT } & \Delta \mathrm{H}(\mathrm{kJ} / \mathrm{mol} .) \\ 1.0 & -381.7\end{array}$

determination. In the pure acetylene system the reaction rate coefficient for bimolecular association was determined to be $2.8 \times 10^{-11} \mathrm{~cm}^{3} \mathrm{~s}^{-1}$ for the reactive component of the $\mathrm{C}_{6} \mathrm{H}_{4}^{+}$products, which was about $50 \%$ of the total $\mathrm{C}_{6} \mathrm{H}_{4}^{+}$ions produced from the 3-body reaction channel [Reaction (B2), $-36 \mathrm{~kJ} /$ mole exothermic] compared with $80 \%$ of those produced by the 2-body reaction channel [Reaction (B3), near thermal]. 


$$
\begin{aligned}
& \left(\mathrm{C}_{6} \mathrm{H}_{5}^{+}\right)^{*}+\mathrm{C}_{2} \mathrm{H}_{2} \quad \rightarrow \mathrm{C}_{8} \mathrm{H}_{7}^{+} \\
& k(I C R)=2.5 \times 10^{-11} \mathrm{~cm}^{3} \mathrm{~s}^{-1} \\
& \mathrm{C}_{6} \mathrm{H}_{5}^{+}+\mathrm{C}_{2} \mathrm{H}_{2}+\mathrm{M} \\
& \rightarrow \mathrm{C}_{8} \mathrm{H}_{7}^{+}+\mathrm{M} \\
& \begin{array}{lll}
\text { ICR } & \text { SIFT } & \Delta \mathrm{H}(\mathrm{kJ} / \mathrm{mol} .) \\
1.0 & -357.7
\end{array} \\
& \mathrm{k}(\mathrm{SIFT}) \mathrm{ac} \leq 8 \times 10^{-12} \mathrm{~cm}^{3} \mathrm{~s}^{-1} \text { in } 0.5 \text { Torr of He } \\
& k(S I F T) c=6.0 \times 10^{-10} \mathrm{~cm}^{3} \mathrm{~s}^{-1} \text { in } 0.5 \text { Torr of He } \\
& \mathrm{k}_{3}(\mathrm{SIFT}) \geq 3.7 \times 10^{-26} \mathrm{~cm}^{6} \mathrm{~s}^{-1}(\mathrm{M}=\mathrm{He})
\end{aligned}
$$

The $\mathrm{C}_{6} \mathrm{H}_{5}^{+}$ion was formed as a product ion in the acetylene system by the exothermic Reaction (B3). The reaction rate coefficient reported here may be smaller than the value measured for the ground state ions. In the pure acetylene system the reaction rate coefficient was determined to be $2.5 \times$
$10^{-11} \mathrm{~cm}^{3} \mathrm{~s}^{-1}$ for bimolecular association from the reactive part of the $\mathrm{C}_{6} \mathrm{H}_{5}^{+}$products, which was about $50 \%$ of the total $\mathrm{C}_{6} \mathrm{H}_{5}^{+}$ions produced from either the 3-body or the 2-body reaction channels. The SIFT study identified the reactive isomer as $c-\mathrm{C}_{6} \mathrm{H}_{5}^{+}[13]$.

$\begin{array}{lll}\text { ICR } & \text { SIFT } & \Delta \mathrm{H}(\mathrm{kJ} / \mathrm{mol} .)\end{array}$

$$
k_{2}(I C R)<1 \times 10^{-12} \mathrm{~cm}^{3} \mathrm{~s}^{-1}
$$

\begin{tabular}{|c|c|c|}
\hline ICR & SIFT & $\Delta \mathrm{H}(\mathrm{kJ} / \mathrm{mol})$. \\
\hline$\overline{1.0}$ & & - \\
\hline
\end{tabular}

The $\mathrm{C}_{8} \mathrm{H}_{6}^{+}$ion in the acetylene system was made via Reaction (B5). A very small association signal could be

$$
\left(\mathrm{C}_{8} \mathrm{H}_{7}^{+}\right)^{*}+\mathrm{C}_{2} \mathrm{H}_{2}
$$$$
\rightarrow \mathrm{C}_{10} \mathrm{H}_{9}^{+}
$$$$
k_{2}(I C R)<1 \times 10^{-12} \mathrm{~cm}^{3} \mathrm{~s}^{-1}
$$

seen but the rate coefficient was too small for an accurate determination.
The $\mathrm{C}_{8} \mathrm{H}_{7}^{+}$ion in the acetylene system is made via Reaction (B6). A very small association signal was again observed but the rate coefficient was too small for an accurate determination.

\section{Reactions in Pure Ethylene}

In the ethylene system, the exact equations for power absorption [14] were generated for the ethylene reaction scheme listed in Table 1. Sets of peak heights for the ions present were collected over a range of pressures of ethylene in the ICR from $1.3 \times 10^{-5}$ torr to $1.0 \times 10^{-2}$ torr. A least squares fit to the raw data gave the reaction rate coefficients and branching ratios reported here. These additional data were then compared to a simple kinetic model [15] that ignored the power absorption equations. A least squares fit to the same raw data gave essentially the same values, provided the peak heights were normalized at each pressure and the time of the ion in the source was short compared to the time in the resonance region. Under these conditions the simple kinetic model analysis of the power absorption peaks is a good approximation within experimental error, to the exact solution using the power absorption equations. The simple kinetic model analysis was then used for all other studies reported in this work.

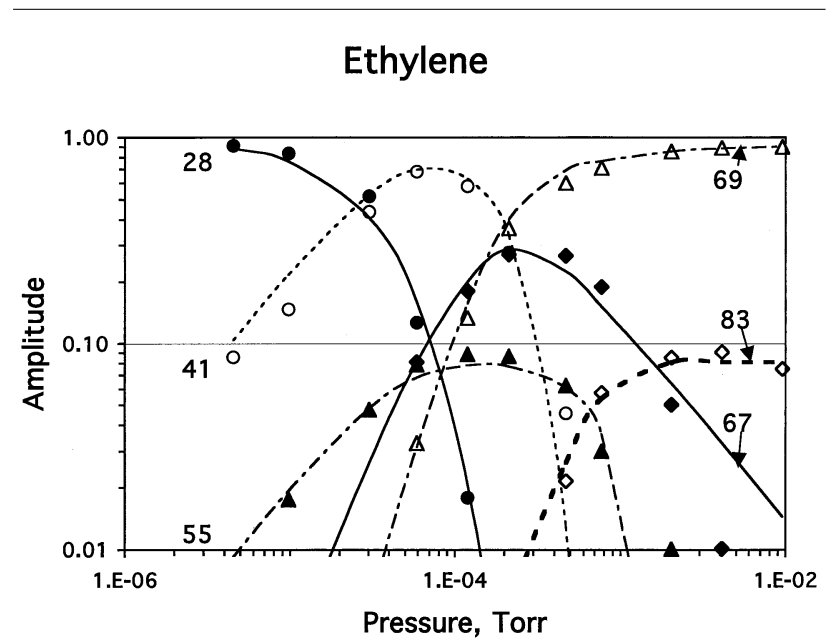

Figure 3. Variation of ion density with pressure in the ICR cell from pure ethylene. The points are experimental and the curves are the model fit derived from the kinetic data described in the text. The numbers next to the data and the curves are the $\mathrm{m} / \mathrm{z}$ of the ions followed.

In Figure 3 the parent ion at mass 28 is seen to decay rapidly with increased pressure. Both of the product ions (mass 41 and 55) undergo further reactions. The mass 55 ion reacts to form the mass 83 ion which does not react further at 10 microns. In the case of the mass 
41 ion, there are two competing loss processes. One channel obeys 2-body kinetics forming mass 67 ions. The other channel has 3-body kinetics forming the mass
69 ion. It can be seen that at a pressure of $1 \times 10^{-4}$ torr, association via 3-body kinetics become the predominant loss channel for the mass 41 ion.

$$
\mathrm{C}_{2} \mathrm{H}_{4}^{+}+\mathrm{C}_{2} \mathrm{H}_{4}
$$

$$
\begin{aligned}
& \rightarrow \mathrm{C}_{3} \mathrm{H}_{5}^{+}+\mathrm{CH}_{3} \\
& \rightarrow \mathrm{C}_{4} \mathrm{H}_{7}^{+}+\mathrm{H}
\end{aligned}
$$

\begin{tabular}{lll} 
ICR & SIFT & $\Delta \mathrm{H}(\mathrm{kJ} / \mathrm{mol})$. \\
\hline 0.93 & -31.8 \\
0.07 & -47.9
\end{tabular}

$$
k(I C R)=7.9 \times 10^{-10} \mathrm{~cm}^{3} \mathrm{~s}^{-1}
$$

The reaction rate coefficient was taken from previous reaction rate coefficients measured. work [10] and is used here as a calibration for the other

$$
\begin{aligned}
& \mathrm{C}_{3} \mathrm{H}_{5}{ }^{+}+\mathrm{C}_{2} \mathrm{H}_{4} \\
& \mathrm{C}_{3} \mathrm{H}_{5}{ }^{+}+\mathrm{C}_{2} \mathrm{H}_{4}+\mathrm{M}
\end{aligned}
$$$$
\rightarrow \mathrm{C}_{5} \mathrm{H}_{7}{ }^{+}+\mathrm{H}_{2}
$$$$
\begin{array}{lll}
\text { ICR } & \text { SIFT } & \Delta \mathrm{H}(\mathrm{kJ} / \mathrm{mol} .) \\
\hline 1.0 & -153.8
\end{array}
$$$$
\mathbf{k}(\mathrm{ICR})=7.7 \times 10^{-11} \mathrm{~cm}^{3} \mathrm{~s}^{-1}
$$$$
\rightarrow \mathrm{C}_{5} \mathrm{H}_{9}{ }^{+}+\mathrm{M}
$$$$
\text { (1.0) } \quad 1.0 \quad-225.8
$$$$
k_{3}(I C R)=1.6 \times 10^{-23} \mathrm{~cm}^{6} \mathrm{~s}^{-1}\left(\mathrm{M}=\mathrm{C}_{2} \mathrm{H}_{4}\right)
$$$$
\mathrm{k}_{3}(\mathrm{ICR})=7.3 \times 10^{-24} \mathrm{~cm}^{6} \mathrm{~s}^{-1}\left(\mathrm{M}=\mathrm{N}_{2}\right)
$$$$
k(S I F T)=5.4 \times 10^{-10} \mathrm{~cm}^{3} \mathrm{~s}^{-1} \text { in } 0.5 \text { Torr of } \mathrm{He}
$$$$
k_{3}(\mathrm{SIFT}) \geq 3.3 \times 10^{-26} \mathrm{~cm}^{6} \mathrm{~s}^{-1}(\mathrm{M}=\mathrm{He})
$$

Termolecular reaction rate coefficients measured for other M's include $\mathrm{CH}_{4}$ and $\mathrm{C}_{2} \mathrm{H}_{4}$. In the SIFT results, two other minor products at $55 \mathrm{a} \mu\left(\mathrm{C}_{4} \mathrm{H}_{7}^{+}\right)$and $57 \mathrm{a} \mu$ $\left(\mathrm{C}_{4} \mathrm{H}_{9}^{+}\right)$were observed, but these were attributed to an impurity. The SIFT results agree with the ICR results at the highest pressures which showed more $\mathrm{m} / \mathrm{z}=69$ than 67 ions at a pressures of $1 \times 10^{-2}$ torr. The simple kinetic model yielded a fit for nitrogen as a third body with a reaction rate coefficient of $\mathrm{k}_{3}=7.3 \times 10^{-24} \mathrm{~cm}^{6}$ $\mathrm{s}^{-1}$.

$$
\begin{aligned}
& \left(\mathrm{C}_{4} \mathrm{H}_{7}^{+}\right)^{*}+\mathrm{C}_{2} \mathrm{H}_{4} \\
& \mathrm{C}_{4} \mathrm{H}_{7}^{+}+\mathrm{C}_{2} \mathrm{H}_{4}+\mathrm{M} \\
& \rightarrow \text { No reaction }
\end{aligned}
$$

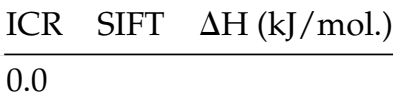

$$
\begin{aligned}
& \mathrm{k}(\mathrm{ICR})<2 \times 10^{-11} \mathrm{~cm}^{3} \mathrm{~s}^{-1} \\
& \rightarrow \mathrm{C}_{6} \mathrm{H}_{11}{ }^{+}+\mathrm{M} \quad 1.0 \quad 1.0 \quad-199.4 \\
& k_{3}(I C R)=1.4 \times 10^{-24} \mathrm{~cm}^{6} \mathrm{~s}^{-1}\left(\mathrm{M}=\mathrm{C}_{2} \mathrm{H}_{4}\right) \\
& k(S I F T)=1.4 \times 10^{-10} \mathrm{~cm}^{3} \mathrm{~s}^{-1} \text { in } 0.5 \text { Torr of He } \\
& k_{3}(\mathrm{SIFT}) \geq 9.0 \times 10^{-27} \mathrm{~cm}^{6} \mathrm{~s}^{-1}(\mathrm{M}=\mathrm{He})
\end{aligned}
$$

\section{Ethane}

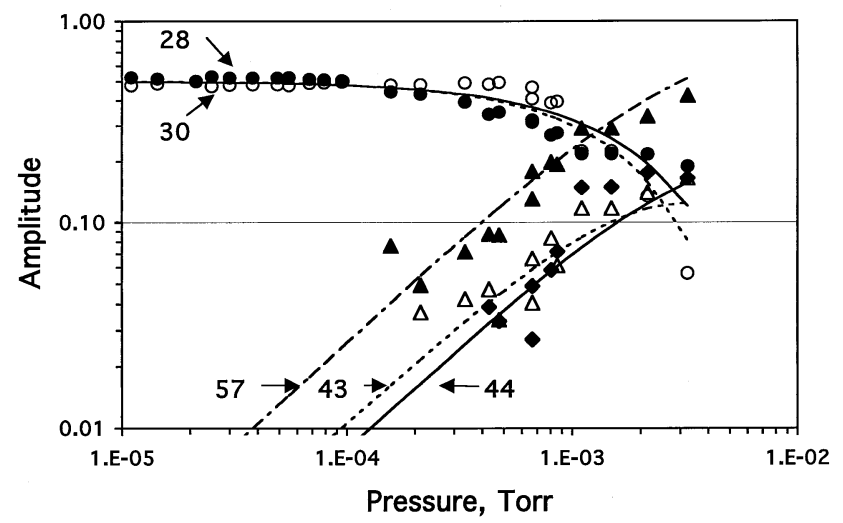

Figure 4. Variation of ion density with pressure in the ICR cell from pure ethane. The points are experimental and the curves are the model fit derived from the kinetic data described in the text. The numbers next to the data and the curves are the $\mathrm{m} / \mathrm{z}$ of the ions followed. 
Subsequent data at much higher pressures $\left(1 \times 10^{-2}\right.$ torr in the ICR) showed an association reaction between $\mathrm{C}_{4} \mathrm{H}_{7}^{+}$and $\mathrm{C}_{2} \mathrm{H}_{4}$. In a study of reactions in a mixture of methane and ethylene, no loss was seen of the $\mathrm{C}_{4} \mathrm{H}_{7}^{+}$ion at $1 \times 10^{-4}$ torr of ethylene which also indicated that the bimolecular association Reaction (C3) is very slow. Even at a total pressure of 0.5 torr of helium in the SIFT, the pseudo-bimolecular reaction rate coefficient was only $1.4 \times 10^{-10} \mathrm{~cm}^{3} \mathrm{~s}^{-1}$ corresponding to a termolecular reaction rate coefficient of greater than or equal to
$9.0 \times 10^{-27} \mathrm{~cm}^{6} \mathrm{~s}^{-1}$.

\section{Reactions in Pure Ethane}

In pure ethane in the ICR the two ions $\mathrm{C}_{2} \mathrm{H}_{4}^{+}$and $\mathrm{C}_{2} \mathrm{H}_{6}^{+}$ were formed by low energy electron impact on $\mathrm{C}_{2} \mathrm{H}_{6}$. Each ion underwent reaction with ethane. Figure 4 shows that the mass 28 and 30 ions decay rather slowly. Note also that the products do not react further at pressures up to 10 microns.

$$
\begin{aligned}
& \text { ICR SIFT } \Delta \mathrm{H}(\mathrm{kJ} / \mathrm{mol}) \\
& \mathrm{C}_{2} \mathrm{H}_{4}{ }^{+}+\mathrm{C}_{2} \mathrm{H}_{6} \quad \rightarrow \mathrm{C}_{3} \mathrm{H}_{7}{ }^{+}+\mathrm{CH}_{3} \\
& k(I C R)=8.0 \times 10^{-12} \mathrm{~cm}^{3} \mathrm{~s}^{-1} \\
& \mathrm{C}_{2} \mathrm{H}_{6}{ }^{+}+\mathrm{C}_{2} \mathrm{H}_{6} \\
& \rightarrow \mathrm{C}_{3} \mathrm{H}_{8}{ }^{+}+\mathrm{CH}_{4}
\end{aligned}
$$

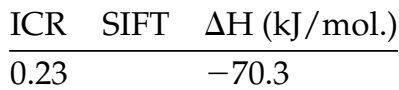

$$
\begin{aligned}
& \rightarrow \mathrm{C}_{4} \mathrm{H}_{9}{ }^{+}+\mathrm{H}_{2}+\mathrm{H} \\
& 0.77 \\
& -19.2 \\
& k(I C R)=2.1 \times 10^{-11} \mathrm{~cm}^{3} \mathrm{~s}^{-1}
\end{aligned}
$$

\section{E. Reactions in Pure Propyne}

With pure propyne in the ICR, the two ions $\mathrm{C}_{3} \mathrm{H}_{3}^{+}$and $\mathrm{C}_{3} \mathrm{H}_{4}^{+}$were formed in the ionization process. Only the $\mathrm{C}_{3} \mathrm{H}_{4}^{+}$ion underwent reaction with propyne. In Figure 5 it can be seen that this system is more complicated than the acetylene system. The increasing complexity is the result of several of the products ions being formed from more than one source. In this system a competition is seen between 2-body and 3-body kinetics in Reaction (E8).

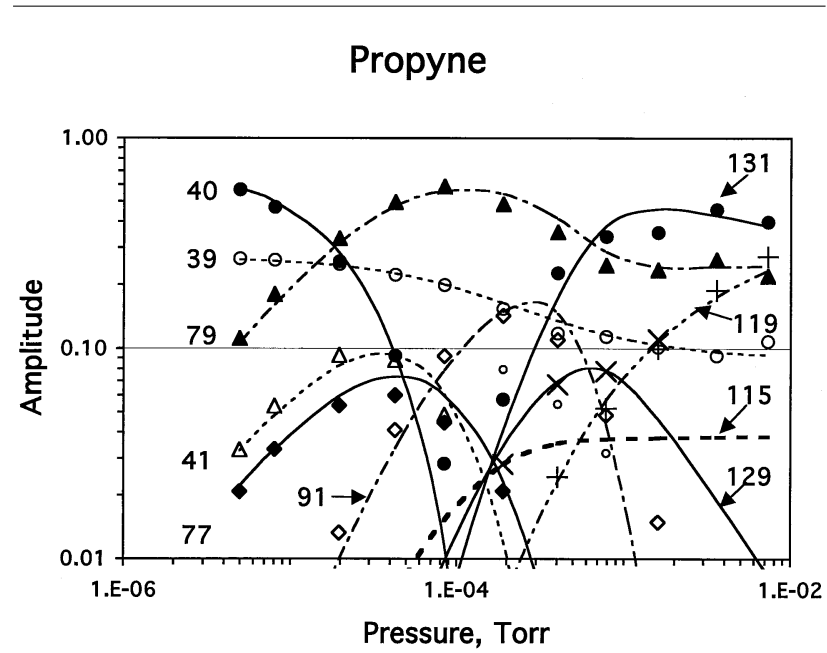

Figure 5. Variation of ion density with pressure in the ICR cell from pure propyne. The points are experimental and the curves are the model fit derived from the kinetic data described in the text. The numbers next to the data and the curves are the $m / z$ of the ions followed. 
propyne are in reasonable agreement with tabulated data [10] for the branching ratios. The two percent channels in the literature studies $\left(\mathrm{C}_{4} \mathrm{H}_{4}^{+}, \mathrm{C}_{4} \mathrm{H}_{6}^{+}\right.$, and $\left.\mathrm{C}_{5} \mathrm{H}_{5}^{+}\right)$ were less than one percent in the present work. Each of the product ions in Reaction (E2) underwent further reaction with propyne. Both $\mathrm{C}_{6} \mathrm{H}_{5}^{+}$and $\mathrm{C}_{6} \mathrm{H}_{7}^{+}$products had at least two distinguishable structures: One reactive to further reaction with propyne and the other unreactive.

$$
\begin{aligned}
& \mathrm{C}_{3} \mathrm{H}_{5}{ }^{+}+\mathrm{C}_{3} \mathrm{H}_{4} \text { (propyne) } \\
& \mathrm{C}_{3} \mathrm{H}_{5}{ }^{+}+\mathrm{C}_{3} \mathrm{H}_{4} \text { (propyne) }+\mathrm{M}
\end{aligned}
$$$$
\rightarrow \mathrm{C}_{6} \mathrm{H}_{7}^{+}+\mathrm{H}_{2}
$$$$
\mathrm{k}(\mathrm{ICR})=3.5 \times 10^{-10} \mathrm{~cm}^{3} \mathrm{~s}^{-1}
$$$$
\begin{array}{lll}
\text { ICR } & \text { SIFT } & \Delta H(\mathrm{~kJ} / \mathrm{mol} .) \\
\hline 1.0 & 0.20 & -268.2
\end{array}
$$$$
\rightarrow \mathrm{C}_{6} \mathrm{H}_{9}{ }^{+}+\mathrm{M}
$$$$
0.80-335.8
$$$$
k(S I F T)=1.2 \times 10^{-9} \mathrm{~cm}^{3} \mathrm{~s}^{-1} \text { in } 0.5 \text { Torr of He }
$$$$
\mathrm{k}_{3}(\mathrm{SIFT}) \geq 6.0 \times 10^{-26} \mathrm{~cm}^{6} \mathrm{~s}^{-1}(\mathrm{M}=\mathrm{He})
$$

The analogous reactions for allene measured in the SIFT

$$
\begin{aligned}
& \mathrm{C}_{3} \mathrm{H}_{5}{ }^{+}+\mathrm{C}_{3} \mathrm{H}_{4}(\text { allene }) \\
& \rightarrow \mathrm{C}_{6} \mathrm{H}_{7}{ }^{+} \\
& \begin{array}{ccc}
\text { ICR } & \text { SIFT } & \Delta \mathrm{H}(\mathrm{kJ} / \mathrm{mol} .) \\
0.25 & -273.4
\end{array} \\
& k(S I F T)=1.1 \times 10^{-9} \mathrm{~cm}^{3} \mathrm{~s}^{-1} \text { in } 0.5 \text { Torr of } \mathrm{He} \\
& \mathrm{C}_{3} \mathrm{H}_{5}{ }^{+}+\mathrm{C}_{3} \mathrm{H}_{4}(\text { allene })+\mathrm{M} \\
& \rightarrow \mathrm{C}_{6} \mathrm{H}_{9}{ }^{+}+\mathrm{M} \\
& 0.75-341.0 \\
& k_{3}(\mathrm{SIFT}) \geq 5.1 \times 10^{-26} \mathrm{~cm}^{6} \mathrm{~s}^{-1}(\mathrm{M}=\mathrm{He}) \\
& \left(\mathrm{C}_{6} \mathrm{H}_{5}{ }^{+}\right)^{*}+\mathrm{C}_{3} \mathrm{H}_{4} \text { (propyne) } \\
& \rightarrow \mathrm{C}_{7} \mathrm{H}_{7}{ }^{+}+\mathrm{C}_{2} \mathrm{H}_{2} \\
& \rightarrow \mathrm{C}_{9} \mathrm{H}_{7}{ }^{+}+\mathrm{H}_{2} \\
& \begin{array}{lll}
\text { ICR } & \text { SIFT } & \Delta \mathrm{H}(\mathrm{kJ} / \mathrm{mol} .) \\
0.70 & -244.7
\end{array} \\
& \mathrm{C}_{6} \mathrm{H}_{5}{ }^{+}+\mathrm{C}_{3} \mathrm{H}_{4} \text { (propyne) }+\mathrm{M} \\
& \rightarrow \mathrm{C}_{9} \mathrm{H}_{9}{ }^{+}+\mathrm{M} \\
& 0.30 \\
& \text { reactive isomer } \mathrm{k}_{3}(\mathrm{ICR})=5.2 \times 10^{-24} \mathrm{~cm}^{6} \mathrm{~s}^{-1}\left(\mathrm{M}=\mathrm{C}_{3} \mathrm{H}_{4}\right) \\
& \mathrm{k}(\mathrm{SIFT})=1.0 \times 10^{-9} \mathrm{~cm}^{3} \mathrm{~s}^{-1} \\
& \mathrm{k}_{3}(\mathrm{SIFT}) \geq 6.2 \times 10^{-26} \mathrm{~cm}^{6} \mathrm{~s}^{-1}(\mathrm{M}=\mathrm{He}) \\
& \text { unreactive isomer } \mathrm{k}_{2}(\mathrm{SIFT}) \leq 1.0 \times 10^{-12} \mathrm{~cm}^{3} \mathrm{~s}^{-1}
\end{aligned}
$$

The $\mathrm{C}_{6} \mathrm{H}_{5}^{+}$ions generated in Reaction (E2) exist in at least two structural forms. The results formed here are for the reactive structure that earlier studies have identified as the cyclic structure [13].

$$
\begin{aligned}
& \left(\mathrm{C}_{6} \mathrm{H}_{7}{ }^{+}\right)^{*}+\mathrm{C}_{3} \mathrm{H}_{4} \text { (propyne) } \\
& \rightarrow \mathrm{C}_{7} \mathrm{H}_{7}^{+}+\mathrm{C}_{2} \mathrm{H}_{4} \\
& k(I C R)=5.6 \times 10^{-11} \mathrm{~cm}^{3} \mathrm{~s}^{-1} \\
& \left(\mathrm{C}_{6} \mathrm{H}_{7}{ }^{+}\right)^{*}+\mathrm{C}_{3} \mathrm{H}_{4} \text { (propyne) }+\mathrm{M} \\
& \rightarrow \mathrm{C}_{9} \mathrm{H}_{11}{ }^{+}+\mathrm{M} \\
& 1.0 \\
& \begin{array}{lll}
\text { ICR } & \text { SIFT } & \Delta \mathrm{H}(\mathrm{kJ} / \mathrm{mol} .) \\
\hline 1.0 & -146.5
\end{array} \\
& k_{3}(I C R)=5.2 \times 10^{-25} \mathrm{~cm}^{6} \mathrm{~s}^{-1}
\end{aligned}
$$

The results shown here are for the more reactive $\mathrm{C}_{6} \mathrm{H}_{7}^{+}$ component that represented $60 \%$ of the total $\mathrm{C}_{6} \mathrm{H}_{7}^{+}$ion count. In the ICR the two isomers were also made from a propyne and ethylene mixture.

The analagous reactions for allene as measured in the SIFT are shown here for comparison.

$$
\begin{aligned}
& \mathrm{C}_{6} \mathrm{H}_{7}{ }^{+} \mathrm{a}+\mathrm{C}_{3} \mathrm{H}_{4}(\text { allene })+\mathrm{M} \\
& \mathrm{C}_{6} \mathrm{H}_{7}{ }^{+} \mathrm{b}+\mathrm{C}_{3} \mathrm{H}_{4}(\text { allene })+\mathrm{M}
\end{aligned}
$$

$$
\rightarrow \mathrm{C}_{9} \mathrm{H}_{11}{ }^{+}+\mathrm{M}
$$$$
\rightarrow \mathrm{C}_{9} \mathrm{H}_{11}{ }^{+}+\mathrm{M}
$$$$
\text { a-k }\left(\text { SIFT) }=1.4 \times 10^{-10} \mathrm{~cm}^{3} \mathrm{~s}^{-1} \text { in } 0.5\right. \text { Torr of He }
$$$$
\text { b-k(SIFT) } \leq 1.0 \times 10^{-12} \mathrm{~cm}^{3} \mathrm{~s}^{-1} \text { in } 0.5 \text { Torr of He }
$$$$
a-k_{3}(\mathrm{SIFT}) \geq 8.6 \times 10^{-27} \mathrm{~cm}^{6} \mathrm{~s}^{-1}(\mathrm{M}=\mathrm{He})
$$ 
In the SIFT the two $\mathrm{C}_{6} \mathrm{H}_{7}^{+}$isomers were generated from hexadiyne and benzene. The more reactive component represented $85-90 \%$ of the total ion count.

\begin{tabular}{lll} 
ICR & SIFT & $\Delta \mathrm{H}(\mathrm{kJ} / \mathrm{mol})$. \\
\hline 1.0 & -169.4
\end{tabular}

$$
\begin{aligned}
& \left(\mathrm{C}_{7} \mathrm{H}_{7}^{+}\right)^{*} \mathrm{a}+\mathrm{C}_{3} \mathrm{H}_{4} \\
& \mathrm{C}_{7} \mathrm{H}_{7}{ }^{+} \mathrm{b}+\mathrm{C}_{3} \mathrm{H}_{4}+\mathrm{M} \\
& \mathrm{C}_{7} \mathrm{H}_{7}{ }^{+} \mathrm{a}+\mathrm{C}_{3} \mathrm{H}_{4}+\mathrm{M}
\end{aligned}
$$

$$
\begin{aligned}
& \rightarrow \mathrm{C}_{10} \mathrm{H}_{9}{ }^{+}+\mathrm{H}_{2} \\
& \mathbf{a}^{-} \mathbf{k}_{\mathbf{2}}(\mathrm{ICR})=\mathbf{1 . 9} \times \mathbf{1 0}^{-11} \mathrm{~cm}^{3} \mathrm{~s}^{-1}
\end{aligned}
$$

$\rightarrow$ No reaction

$\rightarrow \mathrm{C}_{10} \mathrm{H}_{11}{ }^{+}+\mathrm{M}$

$\mathrm{a}-\mathrm{k}_{3}(\mathrm{ICR})=3.7 \times 10^{-24} \mathrm{~cm}^{6} \mathrm{~s}^{-1}\left(\mathrm{M}=\mathrm{C}_{3} \mathrm{H}_{4}\right)$

b-k(SIFT) $\leq 5.0 \times 10^{-13} \mathrm{~cm}^{3} \mathrm{~s}^{-1}$ in 0.5 Torr of He

$\mathrm{a}-\mathrm{k}(\mathrm{SIFT})=5.0 \times 10^{-10} \mathrm{~cm}^{3} \mathrm{~s}^{-1}$ in 0.5 Torr of $\mathrm{He}$

$\mathrm{a}-\mathrm{k}_{3}(\mathrm{SIFT}) \geq 3.1 \times 1.0^{-26} \mathrm{~cm}^{6} \mathrm{~s}^{-1}(\mathrm{M}=\mathrm{He})$
The ICR results are from $\mathrm{C}_{7} \mathrm{H}_{7}^{+}$generated using pure propyne in Reactions (E5) and (E6). In the SIFT however, the $\mathrm{C}_{7} \mathrm{H}_{7}^{+}$ion was made from a mixture of propyne and acetylene. The reactive fraction of $\mathrm{C}_{7} \mathrm{H}_{7}^{+} \mathrm{a}$ represents $60-70 \%$ of the total $\mathrm{C}_{7} \mathrm{H}_{7}^{+}$isomers.

$$
\begin{array}{lllll}
\mathrm{C}_{9} \mathrm{H}_{7}^{+}+\mathrm{C}_{3} \mathrm{H}_{4}+\mathrm{M} & \rightarrow \mathrm{C}_{12} \mathrm{H}_{11}{ }^{+}+\mathrm{M} & \text { ICR } & \text { SIFT } \Delta \mathrm{H}(\mathrm{kJ} / \mathrm{mol} .) \\
& \mathbf{k}(\mathrm{ICR})<\mathbf{2} \times \mathbf{1 0}^{-\mathbf{1 1}} \mathbf{c m}^{3} \mathbf{~ s}^{-\mathbf{1}} & & & \\
& & &
\end{array}
$$

An association product was observed for $\mathrm{C}_{9} \mathrm{H}_{7}^{+}$with propyne but $\mathrm{k}_{3}$ was not measured. The rate coefficient is very much less than the collision rate coefficient.

\section{F. Reactions in Pure Propene}

In pure propene the primary ions generated in the ICR were $\mathrm{C}_{3} \mathrm{H}_{6}^{+}$and $\mathrm{C}_{3} \mathrm{H}_{3}^{+}(36 \%)$ but the $\mathrm{C}_{3} \mathrm{H}_{3}^{+}$ion did not react. In one study at slightly higher electron energies the $\mathrm{C}_{3} \mathrm{H}_{5}^{+}$ion was also produced. The reaction rate coefficient for $\mathrm{C}_{3} \mathrm{H}_{6}^{+}+\mathrm{C}_{3} \mathrm{H}_{6}$ was taken from earlier work [10] and is used here as a calibration for the other rate coefficients measured. In Figure 6 the rapid loss of the parent ion is seen with a corresponding formation of secondary ions. These secondary ions then decay through further reaction with propene. The mass 43 and 55 ions are rapidly converted to mass 57 and mass 69 ions, respectively. The mass 70 ion comes from the mass 56 ion.

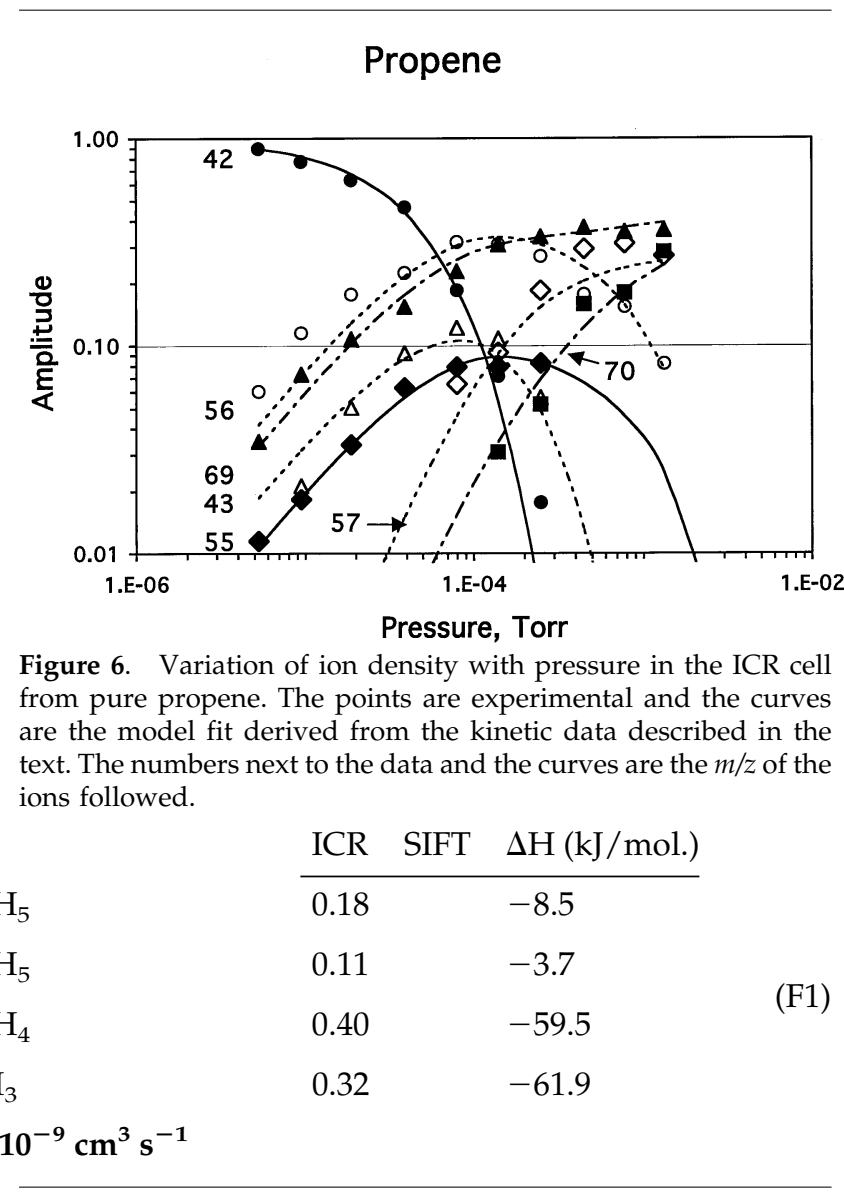




\section{Propane}

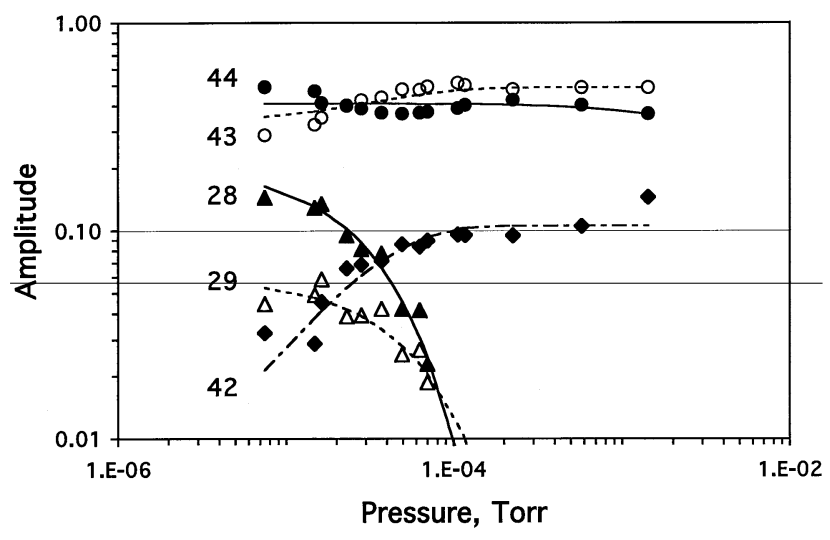

Figure 7. Variation of ion density with pressure in the ICR cell from pure propane. The points are experimental and the curves are the model fit derived from the kinetic data described in the text. The numbers next to the data and the curves are the $\mathrm{m} / \mathrm{z}$ of the ions followed.

\begin{tabular}{|c|c|c|c|c|}
\hline & & ICR & SIFT & $\Delta \mathrm{H}(\mathrm{kJ} / \mathrm{mol})$. \\
\hline \multirow[t]{3}{*}{$\mathrm{C}_{3} \mathrm{H}_{5}^{+}+\mathrm{C}_{3} \mathrm{H}_{6}$} & $\rightarrow \mathrm{C}_{4} \mathrm{H}_{5}^{+}+\mathrm{C}_{2} \mathrm{H}_{6}$ & & 0.10 & -57.8 \\
\hline & $\rightarrow \mathrm{C}_{4} \mathrm{H}_{7}^{+}+\mathrm{C}_{2} \mathrm{H}_{4}$ & 1.0 & 0.70 & -56.3 \\
\hline & $\mathrm{k}(\mathrm{ICR})=1.0 \times 10^{-9} \mathrm{~cm}^{3} \mathrm{~s}^{-1}$ & & & \\
\hline \multirow[t]{4}{*}{$\mathrm{C}_{3} \mathrm{H}_{5}^{+}+\mathrm{C}_{3} \mathrm{H}_{6}+\mathrm{M}$} & $\rightarrow$ association & & 0.20 & -255.8 \\
\hline & $\mathrm{k}(\mathrm{SIFT})=1.2 \times 10^{-9} \mathrm{~cm}^{3} \mathrm{~s}^{-1} \mathrm{i}$ & Torr o & f He & \\
\hline & $\mathrm{k}_{3}(\mathrm{SIFT}) \geq 1.5 \times 10^{-26} \mathrm{~cm}^{6} \mathrm{~s}^{-}$ & 5 Torr & of $\mathrm{He}$ & \\
\hline & & ICR & SIFT & $\Delta \mathrm{H}(\mathrm{kJ} / \mathrm{mol})$. \\
\hline \multirow[t]{3}{*}{$\mathrm{C}_{3} \mathrm{H}_{7}^{+}+\mathrm{C}_{3} \mathrm{H}_{6}$} & $\rightarrow \mathrm{C}_{4} \mathrm{H}_{9}^{+}+\mathrm{C}_{2} \mathrm{H}_{4}$ & 1.0 & & -58.0 \\
\hline & $\mathrm{k}(\mathrm{ICR})=4.5 \times 10^{-10} \mathrm{~cm}^{3} \mathrm{~s}^{-1}$ & & & \\
\hline & & ICR & SIFT & $\Delta \mathrm{H}(\mathrm{kJ} / \mathrm{mol})$. \\
\hline \multirow[t]{3}{*}{$\mathrm{C}_{4} \mathrm{H}_{7}^{+}+\mathrm{C}_{3} \mathrm{H}_{6}$} & $\rightarrow \mathrm{C}_{5} \mathrm{H}_{9}{ }^{+}+\mathrm{C}_{2} \mathrm{H}_{4}$ & $\overline{1.0}$ & & -52.9 \\
\hline & $\mathrm{k}(\mathrm{ICR})=5.6 \times 10^{-11} \mathrm{~cm}^{3} \mathrm{~s}^{-1}$ & & & \\
\hline & & ICR & SIFT & $\Delta \mathrm{H}(\mathrm{kJ} / \mathrm{mol})$. \\
\hline \multirow[t]{3}{*}{$\mathrm{C}_{4} \mathrm{H}_{8}^{+}+\mathrm{C}_{3} \mathrm{H}_{6}$} & $\rightarrow \mathrm{C}_{4} \mathrm{H}_{9}^{+}+\mathrm{C}_{3} \mathrm{H}_{5}$ & 0.24 & & -6.6 \\
\hline & $\rightarrow \mathrm{C}_{5} \mathrm{H}_{10}{ }^{+}+\mathrm{C}_{2} \mathrm{H}_{4}$ & 0.76 & & -39.2 \\
\hline & $\mathrm{k}(\mathrm{ICR})=8.6 \times 10^{-11} \mathrm{~cm}^{3} \mathrm{~s}^{-1}$ & & & \\
\hline
\end{tabular}

\section{G. Reactions in Pure Propane}

The primary ions generated with pure propane in the ICR cell were $\mathrm{C}_{3} \mathrm{H}_{8}^{+}, \mathrm{C}_{3} \mathrm{H}_{7}^{+}, \mathrm{C}_{2} \mathrm{H}_{4}^{+}$, and $\mathrm{C}_{2} \mathrm{H}_{5}^{+}$. In Figure 7 it can be seen that the $\mathrm{C}_{3} \mathrm{H}_{\mathrm{n}}^{+}$ions do not react with propane at pressures up to one micron. The only reactions observed come from the ions $\mathrm{C}_{2} \mathrm{H}_{4}^{+}$and $\mathrm{C}_{2} \mathrm{H}_{5}^{+}$ that are fragment ions derived from electron impact on propane. 


$$
\mathrm{C}_{2} \mathrm{H}_{4}^{+}+\mathrm{C}_{3} \mathrm{H}_{8}
$$$$
\mathrm{C}_{2} \mathrm{H}_{5}{ }^{+}+\mathrm{C}_{3} \mathrm{H}_{8}
$$$$
\mathrm{C}_{3} \mathrm{H}_{6}{ }^{+}+\mathrm{C}_{3} \mathrm{H}_{8}
$$

$$
\begin{aligned}
& \rightarrow \mathrm{C}_{3} \mathrm{H}_{6}{ }^{+}+\mathrm{C}_{2} \mathrm{H}_{6} \\
& \rightarrow \mathrm{C}_{3} \mathrm{H}_{7}{ }^{+}+\mathrm{C}_{2} \mathrm{H}_{5} \\
& \mathbf{k}(\text { ICR })=\mathbf{9 . 4} \times \mathbf{1 0}^{-10} \mathbf{c m}^{3} \mathbf{s}^{-1} \\
& \mathbf{k}(\mathrm{SIFT})=\mathbf{1 . 1} \times \mathbf{1 0}^{-9} \mathbf{c m}^{3} \mathbf{s}^{-1}
\end{aligned}
$$$$
\rightarrow \mathrm{C}_{3} \mathrm{H}_{7}{ }^{+}+\mathrm{C}_{2} \mathrm{H}_{6}
$$$$
\text { ICR SIFT } \Delta \mathrm{H}(\mathrm{kJ} / \mathrm{mol} .)
$$$$
\mathrm{k}(\mathrm{ICR})=4.8 \times 10^{-10} \mathrm{~cm}^{3} \mathrm{~s}^{-1}
$$$$
\mathrm{k}(\mathrm{SIFT})=6.6 \times 10^{-10} \mathrm{~cm}^{3} \mathrm{~s}^{-1}
$$

\begin{tabular}{lll} 
ICR & SIFT & $\Delta \mathrm{H}(\mathrm{kJ} / \mathrm{mol})$. \\
\hline 0.52 & & -90.5 \\
0.48 & & -46.6
\end{tabular}$$
\text { ICR SIFT } \Delta \mathrm{H}(\mathrm{kJ} / \mathrm{mol} .)
$$$$
\rightarrow \text { no reaction }
$$$$
0.0
$$

$$
\mathrm{k}(\mathrm{ICR})<3.0 \times 10^{-12} \mathrm{~cm}^{3} \mathrm{~s}^{-1}
$$

In the SIFT experiment the $\mathrm{C}_{3} \mathrm{H}_{7}^{+}$ion was made by electron impact fragmentation of n-butane.

$$
\begin{aligned}
& \mathrm{C}_{3} \mathrm{H}_{7}{ }^{+}+\mathrm{C}_{3} \mathrm{H}_{8} \\
& \rightarrow \text { No reaction } \\
& \text { ICR SIFT } \Delta \mathrm{H}(\mathrm{kJ} / \mathrm{mol} \text {.) } \\
& k(I C R)<3.0 \times 10^{-12} \mathrm{~cm}^{3} \mathrm{~s}^{-1} \\
& k(\mathrm{SIFT})<1.0 \times 10^{-12} \mathrm{~cm}^{3} \mathrm{~s}^{-1} \\
& 0.0 \quad 0.0 \\
& \text { ICR SIFT } \Delta \mathrm{H}(\mathrm{kJ} / \mathrm{mol} \text {.) } \\
& \mathrm{C}_{3} \mathrm{H}_{8}{ }^{+}+\mathrm{C}_{3} \mathrm{H}_{8} \\
& \rightarrow \text { No reaction } \\
& 0.0 \\
& \mathrm{k}(\mathrm{ICR})<3.0 \times 10^{-12} \mathrm{~cm}^{3} \mathrm{~s}^{-1}
\end{aligned}
$$

\section{H. Reactions in Pure Diacetylene}

The primary ion generated from diacetylene in the ICR cell was $\mathrm{C}_{4} \mathrm{H}_{2}^{+}$and the ensuing reactions are seen in Figure 8. It can be seen by reference to Figure 8 that the primary ion at mass 50 reacts to form the mass 74 ion, which in turn reacts to form the mass 98 and 124 ions. The mass 98 ion reacts to form the mass 148 ion.

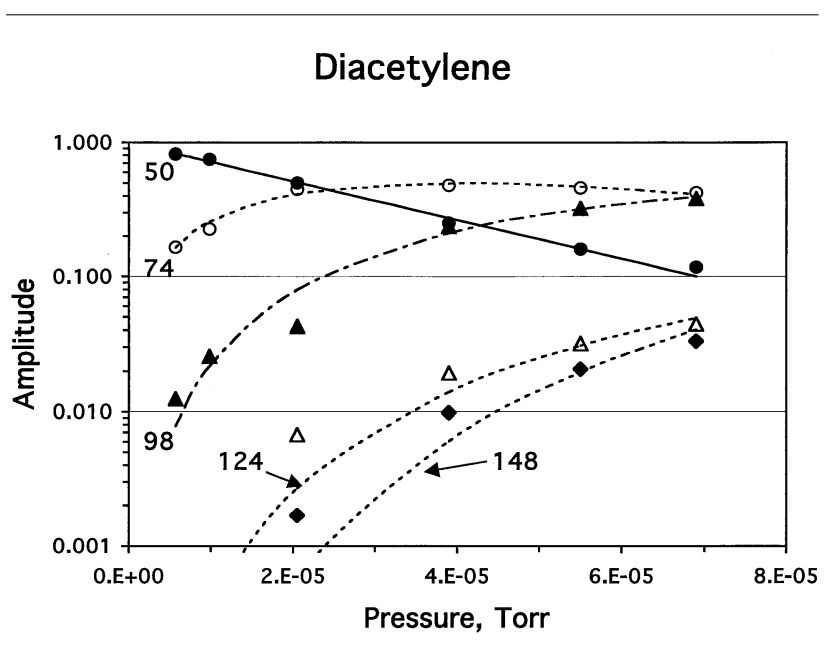

Figure 8. Variation of ion density with pressure in the ICR cell from pure diacetylene. The points are experimental and the curves are the model fit derived from the kinetic data described in the text. The numbers next to the data and the curves are the $\mathrm{m} / \mathrm{z}$ of the ions followed. 
$\mathrm{C}_{4} \mathrm{H}_{2}{ }^{+}+\mathrm{C}_{4} \mathrm{H}_{2}$

$\mathrm{C}_{6} \mathrm{H}_{2}{ }^{+}+\mathrm{C}_{4} \mathrm{H}_{2}$

$\mathrm{C}_{6} \mathrm{H}_{2}^{+}+\mathrm{C}_{4} \mathrm{H}_{2}+\mathrm{C}_{4} \mathrm{H}_{2}$

$\mathrm{C}_{8} \mathrm{H}_{2}{ }^{+}+\mathrm{C}_{4} \mathrm{H}_{2}+\mathrm{C}_{4} \mathrm{H}_{2}$ $\rightarrow \mathrm{C}_{6} \mathrm{H}_{2}{ }^{+}+\mathrm{C}_{2} \mathrm{H}_{2}$

$k(I C R)=1.4 \times 10^{-9} \mathrm{~cm}^{3} \mathrm{~s}^{-1}$

\begin{tabular}{lll} 
ICR & SIFT & $\Delta \mathrm{H}(\mathrm{kJ} / \mathrm{mol})$. \\
\hline 1.0 & -273.5
\end{tabular}

\begin{tabular}{lll} 
ICR & SIFT & $\Delta \mathrm{H}(\mathrm{kJ} / \mathrm{mol})$. \\
\hline 1.0 & -237.3
\end{tabular}

$k(I C R)=6.7 \times 10^{-10} \mathrm{~cm}^{3} \mathrm{~s}^{-1}$

\begin{tabular}{lll} 
ICR & SIFT & $\Delta \mathrm{H}(\mathrm{kJ} / \mathrm{mol})$. \\
\hline 1.0 & -739.0
\end{tabular}

$\rightarrow \mathrm{C}_{10} \mathrm{H}_{4}^{+}+\mathrm{C}_{4} \mathrm{H}_{2}$
$\mathbf{k}(\mathrm{ICR})=3.4 \times \mathbf{1 0}^{-23} \mathbf{c m}^{6} \mathrm{~s}^{-1}$

\begin{tabular}{lll} 
ICR & SIFT & $\Delta \mathrm{H}(\mathrm{kJ} / \mathrm{mol})$. \\
\hline 1.0 & -739.0
\end{tabular}

\section{Conclusions}

A new method for analyzing the ion chemistry of complex systems has been successfully applied to the ion-neutral chemistry of hydrocarbons. The hydrocarbons chosen in this study have all been identified as components of the atmosphere of Titan [16]. It is usual in most ion-molecule reaction studies to first generate the ion of interest from a molecule known to produce the ion either by direct ionization or by fragmentation of the molecule, so as to give the maximum ion signals. The reactivity of that ion with the neutral is then investigated. However, in Titan's ionosphere, many ions are produced as products of ion-molecule reactions and these ions can retain some of the energy from their formation process. Also many hydrocarbon ions at a particular $\mathrm{m} / \mathrm{z}$ can have several possible structures. Thus, the common methodology for investigating ionneutral reactions does not necessarily lead to an accurate evaluation of the ion chemistry of those ions in Titan's ionosphere.

In this work, the sequences of ion-molecule reactions in hydrocarbons or mixtures of hydrocarbons were followed. In adapting this approach we are approximating more closely to those ion structures that are likely to be present on Titan. Further, the extension to higher pressures than are traditionally used in ICR techniques has enabled us to explore the onset of termolecular association reactions. The ability to then examine those same processes in the much higher pressure SIFT experiment provides additional information on the association process.

There are several important conclusions from this work. The fact that we can model the ion abundance data to the highest pressures attainable in the ICR cell means that the fundamental reaction rate coefficients and branching ratios for each reaction in the sequence of reactions are now well understood. It is significant however, that the presence of internal energy in ions that have been formed from a preceding ion-molecule reaction can influence both the rate coefficients and branching ratios of some reactions. Some excited ions formed in a similar manner to the ions in this study will be present in Titan's ionosphere. The nominal pressuretemperature model of Titan's atmosphere has been presented by Fox and Yelle [17]. The nitrogen composes the vast majority of the atmosphere with methane being the most reactive component to the ion population and it is nominally $\sim 2 \%$ of the total atmosphere [16]. The population of free electrons has been presented in a model of Keller et al. [18] for the upper ionosphere and a model of Molina-Cuberos et al. for the cosmic ray induced ionosphere [19]. If it is assumed the electron recombination reaction rate coefficient is $2 \times 10^{-7}$ $\mathrm{cm}^{3} \mathrm{~s}^{-1}$, then the ion half-life time toward electron recombination can be calculated. There are two minima of the ion half-life time toward electron recombination in Titan's atmosphere, one at $1050 \mathrm{~km}$ of $600 \mathrm{~s}$ and the other at $90 \mathrm{~km}$ of $1400 \mathrm{~s}$. There is plenty of time for radiative cooling of the ions excess energy if the ion is unreactive. The ions will be colliding with the nitrogen molecules in Titan's atmosphere. The half-life of ion collisions with the nitrogen is $1 \mu \mathrm{s}$ at $2000 \mathrm{~km}, 10 \mathrm{ps}$ at $1000 \mathrm{~km}$ and substantially shorter at lower altitudes. It is expected that collisional cooling of the "hot" ions will be more efficient than the radiative cooling. If the ion reacts with methane, there will statistically be 50 collisions with the nitrogen before a collision with methane occurs. If the nitrogen can cool the "hot" ions in 50 collisions than the ion will be thermalized for the methane reaction. For reactions with acetylene the nitrogen will have 200 collisions to cool the "hot" ions. It is conceivable that some ions will not be cooled before undergoing reaction in Titan's atmosphere, therefore 
care must be taken in choosing reaction rate coefficients in the modeling process. Even in the SIFT flow tube at pressures around 0.5 torr, some of the smaller ions may retain their excitation even after 65,000 collisions with the helium bath gas.

Finally, we note that ion association reactions are common in hydrocarbon systems and these association reactions will have a pronounced influence on Titan's ion chemistry. On Earth, ion-neutral association plays a role in the D-region ionosphere. It allows the formation of electrostatically-bound clusters of $\mathrm{NO}^{+}$and $\mathrm{O}_{2}^{+}$with $\mathrm{N}_{2}$ that are eventually switched out to $\mathrm{H}_{3} \mathrm{O}^{+}\left(\mathrm{H}_{2} \mathrm{O}\right)_{n}$ ions. On Titan, the lower temperatures and much stronger covalently-bound structures from association reactions that are formed in hydrocarbon systems, result in the role of association being more important on Titan than it is on Earth. For example, we observed rate coefficients at room temperature for the association of $\mathrm{C}_{3} \mathrm{H}_{5}^{+}$with $\mathrm{C}_{2} \mathrm{H}_{4}$ of $\mathrm{k}_{3}=1.6 \times 10^{-23} \mathrm{~cm}^{6} \mathrm{~s}^{-1}$. At $170 \mathrm{~K}$, we might expect this to increase to $\mathrm{k} \sim 2 \times 10^{-22} \mathrm{~cm}^{6} \mathrm{~s}^{-1}$ assuming a negative temperature dependence of $\sim 2.5$ which is common in these types of reactions where the binding energy (362 $\mathrm{kJ} \mathrm{mol}^{-1}$ ) is large [20]. Clearly, termolecular association reactions with rate coefficients of this magnitude will compete effectively with bimolecular reactions on Titan up to an altitude of $750 \mathrm{~km}$.

\section{Acknowledgments}

The authors thank the Marsden Fund for financial support for this project. Part of this work was carried out at the Jet Propulsion Laboratory, California Institute of Technology, under contract with the National Aeronautics and Space Administration.

\section{References}

1. Anicich, V. G.; Milligan, D. B.; Fairley, D. A.; McEwan, M. J.Termolecular Ion-Molecule Reactions in Titan's Atmosphere. I. Principal Ions with Principal Neutrals. Icarus 2000, 146, 118-124.

2. Milligan, D. B.; Freeman, C. G.; Maclagan, R. G. A. R.; McEwan, M. J.; Wilson, P. F.; Anicich, V. G.Termolecular Ion-Molecule Reactions in Titan's Atmosphere. II. The Structure of the Association Adducts of $\mathrm{HCNH}^{+}$with $\mathrm{C}_{2} \mathrm{H}_{2}$ and $\mathrm{C}_{2} \mathrm{H}_{4}$. J. Am. Soc. Mass Specrom. 2000, 12, 557-564.

3. Anicich, V. G.; McEwan, M. J.Termolecular Ion-Molecule Reactions in Titan's Atmosphere. III. Clustering of Ions. Icarus 2001, 154, 522-530.
4. Keller, C. N.; Anicich, V. G.; Cravens, T. E.Model of Titan's Ionosphere with Detailed Hydrocarbon Ion Chemistry. Planetary Space Sci. 1998, 46, 1157-1174.

5. Banaszkiewicz, M.; Lara, L. M.; Rodrigo, R.; Lopez-Moreno, J. J.; Molina-Cuberos, G. J.A Coupled Model of Titan's Atmosphere and Ionosphere. Icarus 2000, 147, 386-404.

6. McEwan, M. J.; Denison, A. B.; Anicich, V. G.; Huntress, W. T., Jr.Association Reactions at Low Pressure. I. Collision-Stabilized Association Below 1 Micron. Int. J. Mass Spectrom. Ion Processes 1987, 81, 247-257.

7. Wronka, J.; Ridge, D. P.Frequency-Swept Detector for Ion Cyclotron Resonance Mass Spectrometry. Rev. Sci. Instrum. 1982, 53, 491-498.

8. McMahon, T. B.; Beauchamp, J. L.Versatile Trapped Ion Cell for Ion-Cyclotron Resonance Spectroscopy. Rev. Sci. Instrum. 1972, 43, 509.

9. Milligan, D. B.; Fairley, D. A.; Freeman, C. G.; McEwan, M. J.A Flowing Afterglow Selected Ion Flow Tube (FA/SIFT) Comparison of SIFT Injector Flanges and $\mathrm{H}_{3}^{+}+\mathrm{N}$ Revisited. Int. J. Mass Spectrom. 2000, 202, 351-361.

10. Anicich, V. G.; McEwan, M. J.Ion-Molecule Chemistry in Titan's Ionosphere. Planetary Space Sci. 1997, 45, 897-921.

11. Knight, J. S.; Freeman, C. G.; McEwan, M. J.; Anicich, V. G.; Huntress, W. T., Jr.A Flow Tube Study of Ion-Molecule Reactions of Acetylene. J. Phys. Chem. 1987, 91, 3898-3902.

12. Anicich, V. G.; Sen, A. D.; Huntress, W. T., Jr.; McEwan, M. J.Association Reactions at Low Pressure. III. The $\mathrm{C}_{2} \mathrm{H}_{2}^{+}$/ $\mathrm{C}_{2} \mathrm{H}_{2}$ System. J. Chem. Phys. 1990, 93, 7163-7172.

13. Scott, G. B. I.; Fairley, D. A.; Freeman, C. G.; McEwan, M. J.; Adams, N. G.; Babcock, L. M. $\mathrm{C}_{\mathrm{m}} \mathrm{H}_{\mathrm{n}}^{+}$Reactions with $\mathrm{H}$ and $\mathrm{H}_{2}$ : An Experimental Study. J. Phys. Chem. A 1997, 101, 4973-4978.

14. Comisarow, M. B.Comprehensive Theory for Ion Cyclotron Resonance Power Absorption: Application to Line Shapes for Reactive and Nonreactive Ions. J. Chem. Phys. 1971, 55, 205217.

15. Sen, A. D.; Huntress, W. T., Jr.; Anicich, V. G.; McEwan, M. J.; Denison, A. B.Association Reactions at Low Pressure. IV. The $\mathrm{HC}_{3} \mathrm{~N}^{+} / \mathrm{HC}_{3} \mathrm{~N}$ System. J. Chem. Phys. 1991, 94, 5462-5470.

16. Toublanc, D.; Parisot, J. P.; Brillet, J.; Gautier, D.; Raulin, F.; McKay, C. P.Photochemical Modeling of Titan's Atmosphere. Icarus 1995, 113, 2-26.

17. Fox, J. L.; Yelle, R. V.Hydrocarbons Ions in the Ionosphere of Titan. Geophys. Res. Letts. 1991, 24, 2179-2182.

18. Keller, C N..; Anicich, V. G.; Cravens, T. E.Model of Titan's Ionosphere with detailed Hydrocarbon Ion Chemistry. Planetary Space Sci. 1998, 46, 1157-1174.

19. Molina-Cuberos, G. J.; Lopez-Moreno, Rodrigo R.; Lara, L. M.Chemistry of the Galactic Cosmic Ray Inducted Ionosphere. J. Geophys. Res. 1999, 104, 21997-22024.

20. Bates, D. R.; Herbst, E.. Radiative Association in Reaction Rate Coefficients in Astrochemistry; Millar, T. J.; Williams, D. A., Ed.; Kluwer Academic Publishers: Dortrecht, 1988; 17-40. 